\title{
The Role of Organizational Environment in Enhancing Managerial Empowerment in Al-Aqsa Network for Media and Art Production
}

\author{
Alaa Hassan Ali Afana* \\ Al-Aqsa Media Network Institution, \\ Gaza Strip, Palestine. \\ Email:Afana2012@gmail.com

\section{Adeeb Salem EL Agha} \\ The Academy of Management and Politics for Postgraduate Studies and Al-Aqsa University, \\ Gaza, Palestine. \\ Email: as.elagha@alaqsa.edu.ps
}

Received February, 2019; Accepted May, 2019

\begin{abstract}
This study aims at identifying the role of organizational environment in enhancing the managerial empowerment of employees at Al-Aqsa Network for Media and Art Production. To achieve the objectives of the present study, the researcher used the analytical descriptive approach, and a survey was used as the main tool for collecting the necessary data. The study sample consisted of (67) employees holding supervisory positions who were selected in a complete census method for all employees in supervisory positions at Al-Aqsa network for Media and Art production. 67 questionnaires were distributed, while the number of recovered questionnaires was (61) valid for the purposes of statistical analysis at a response rate of $(91 \%)$. The results showed that there is a statistically significant role at the level of $(\alpha \leq 0.05)$ between the organizational environment in the following areas (organizational culture, organizational structure and organizational resources) and the enhancing the administrative empowerment. The organizational structure field was the strongest area in association with the organizational environment. In addition, the study concluded that the dimensions of organizational environment have a statistically positive and significant effect at the level of $(\alpha \leq 0.05)$ in enhancing the administrative empowerment.
\end{abstract}

Keywords: Organizational Environment; Managerial Empowerment, Al-Aqsa Network, Palestine

Type: Research paper

This work is licensed under a Creative Commons Attribution 4.0 International License.

$$
\begin{aligned}
& \text { DOI: } 10.51325 / \text { ijbeg.v2i2.40 } \\
& \text { دور البيئة التظيمية في تعزيز التمكين الإداري في شبكة الأقصى للإعلام والإنتاج الفني } \\
& \text { هدفت هذه الدراسـة إلى التعرف على دور البيئة التظظيمية في تعزيز التمكين الإداري لدى العاملين في شبكة } \\
& \text { الأقصى للإعلام والإنتاج الفني. ولتحقيق أهداف الدراسة الحالية، استُخدم المنهج الوصفي التحليلي وأيضـاً الاستبانة } \\
& \text { كأداة رئيسة لجمع البيانات الضرورية. وتكونت عينة الدراسة من (67) موظفاً ممن يشغلون الوظائف الإشرافية، تم } \\
& \text { اختيارهم بطريقة الحصر الثامل لجميع العاملين في الوظائف الإشرافية للعاملين بشبكة الأقصى للإعلام والإنتاج } \\
& \text { والفني. وتم توزيع (67) استبانة، وكان عدد الاستبانات المستردة (61) استبانة صـالحة لغايات التحليل الإحصسئي } \\
& \text { بمعدل اسـتجابة (91\%)، وتم تحليـل البيانـات باسـخدام برنـامج الـرزم الإحصـائية للعلـوم الاجتماعيـة (SPSS). } \\
& \text { وتوصـلت الدراسـة إلى أنـه يوجد أثر ذو دلالـة إحصـائية عند مستوى (0.05 م) بين البيئة التتظيميـة والمتمثلـة } \\
& \text { بالمجالات التالية (الثقافة التظيمية، الهيكل التظيمي، والموارد التظيمية) وتعزيز التمكين الإداري، وقد كان أقوى }
\end{aligned}
$$


المجالات ارتباطاً مع البيئة التنظيمية مجال الهيكل التظيمي. كما أنه خلصت الدراسة إلى أن أبعاد البيئة التتظيمية تؤثر تأثيراً ايجابيا وجوهرياً ذو دلالة إحصائية عند مستوى دلالة (ك0.05ه) في تعزيز التمكين الإداري.

الكلمات المفتاحية: البيئة التتظيمية، التمكين الإداري، شبكة الأقصى، فلسطين

مقدمة الدراسة

يُعتبر المورد البشري هو المسئول الأول عن نجاح أو فثل المنظمة، وهو أحد مقوماتها، التي يجب الحفاظ عليها 31

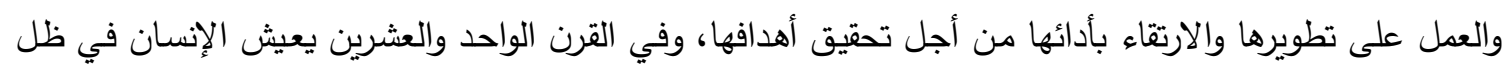

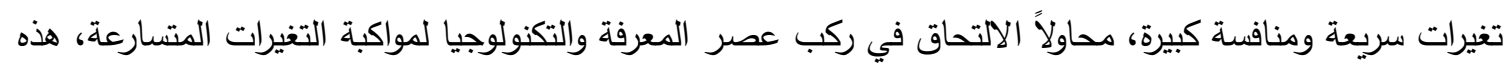
التغيرات تتطلب من المنظمات أن ترقى بمستوى إداراتها لتتمكن من مواجهة التطورات العلمية الحديثة، وهذا يتطلب

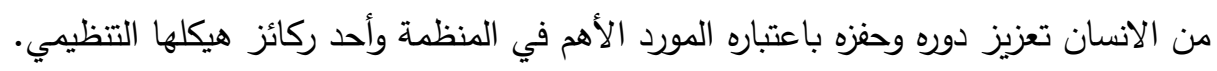
إن المحور الجوهري للمنظمات المبدعة يقوم على تطويرها لبيئة تتظيمية تعمل على بلورة الاتجاهات الإبداعية في

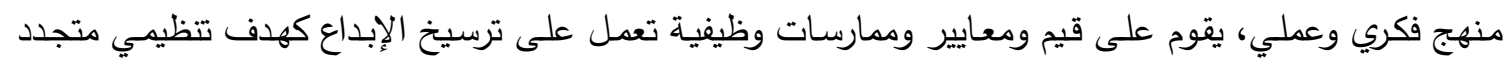

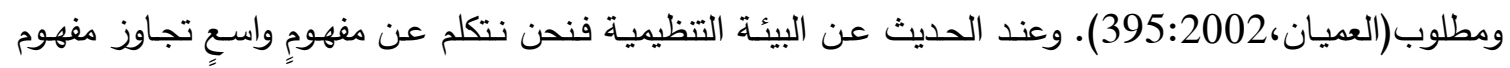

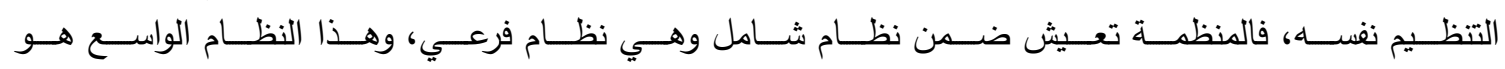

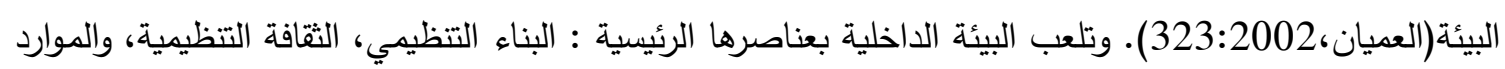

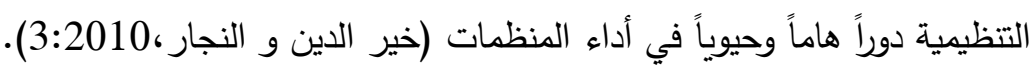

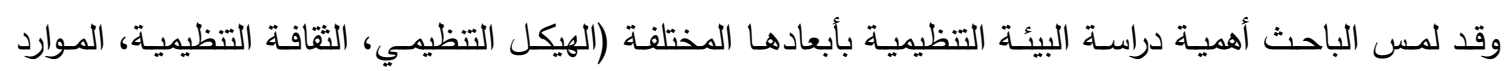

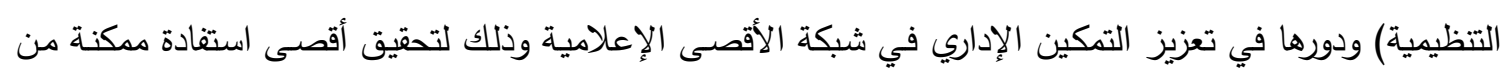

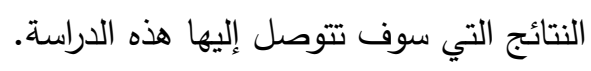

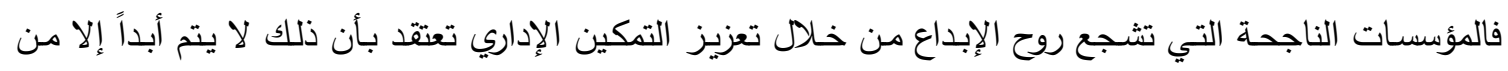

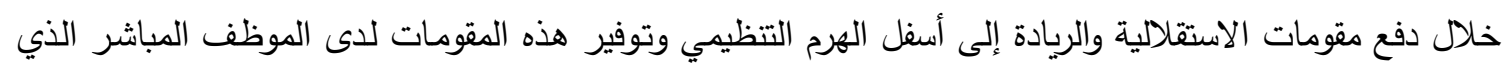

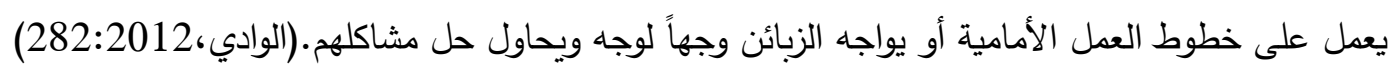

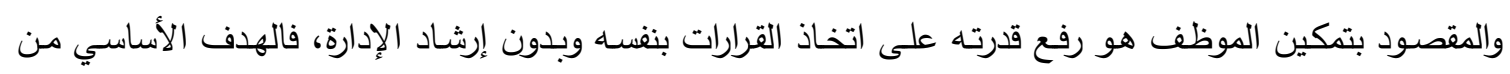
التمكين توفير الظروف للسماح لكافة الموظفين بأن يساهموا بأقصى طاقتهم في جهود التحسين المستمر ، وبالتالي

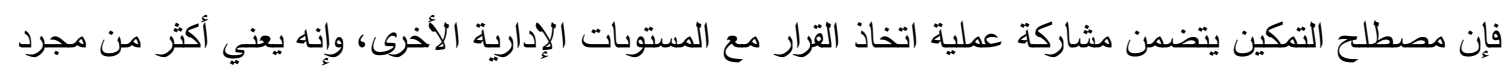

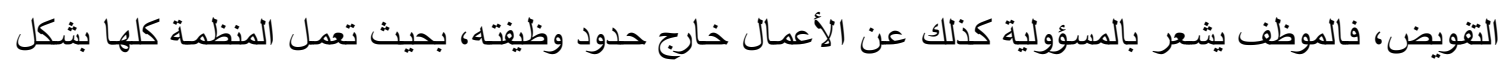
أفضل (العطار ، 2:2012).

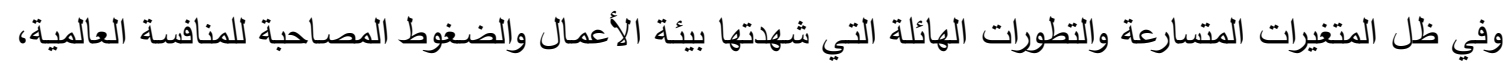
كان لزاماً على معظم المنظمات سواء الحكومية أو الخاصة الاهتمام بتطبيق المفاهيم الإدارية الحديثة وذلك لتحقيق

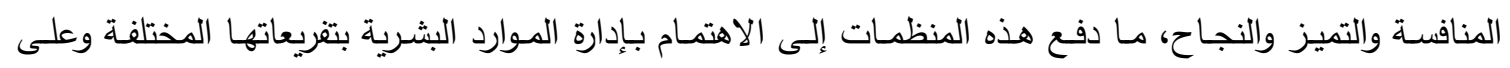

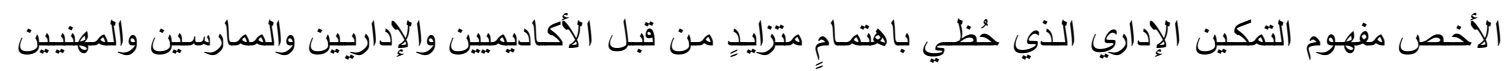

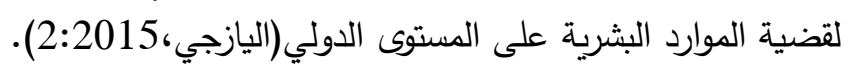
وفي ضوء ما سبق، يرى الباحث أن العنصر البشري في شبكة الأقصى الإعلامية هو أهم مورد من مواردها ويعتبر

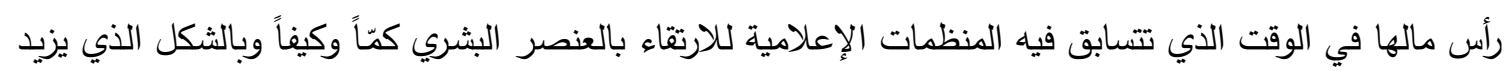


من أدائها وفاعليتها، لذا سيقوم الباحث بالتعرف على دور البيئة التظيمية في تعزيز التمكين الإداري للعاملين في

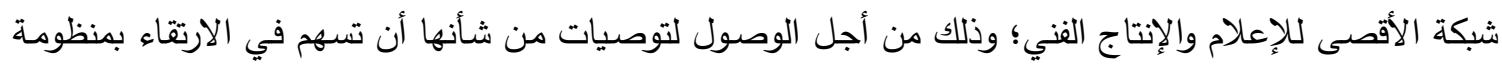
العمل في هذه المنظمة الرائدة. مشكلة الدراسة: على الرغم من أن إدارة شبكة الأقصى الإعلامية على علم كافٍ ودراية علمية واعية بأن العالم يتغير بسرعة كبيرة

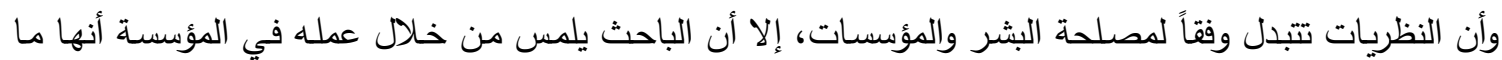
زالت تدير مؤسساتها بنظريات إدارية تقليدية. فالددير البيروقراطي التقليدي ينظر إلى القوانين على أنها غاية ووسيلة معاً، لذلك تفعل البيروقراطية فعلها في كبح

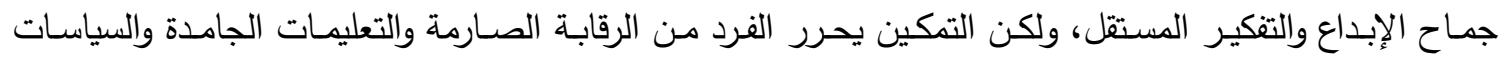

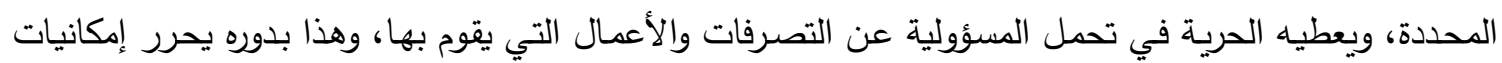

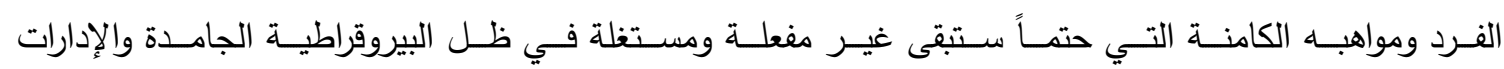
المستبدة(الوادي، 2012:22:

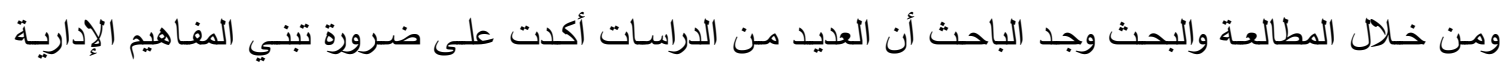

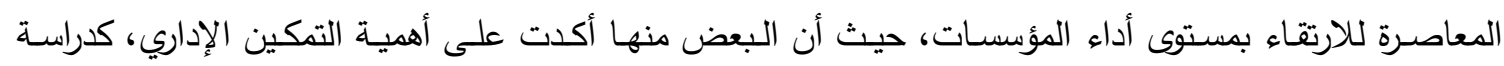
(الزاملي،2013) التي تحدثت عن التمكين الإداري وعلاقته بالإبداع الإداري لاى مديري مدارس وكالة الغوث الدولية في محافظـات غزة، ودراسة(شقورة2015)التي تتاولت منطلبات التمكين الإداري لدى مديري المدارس الثانويـة

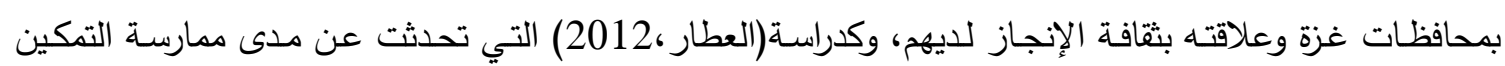
الإداري وتأثير ذلك على إبداع العاملين" دراسة مقارنة لوجهات نظر العاملين في جامعتي الأزهر والإسلامية بغزة.

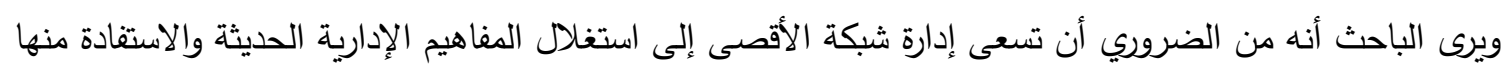

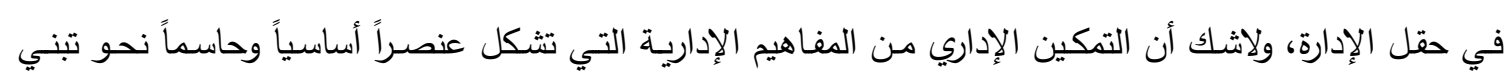
وتطبيق مفاهيم إدارية معاصرة.

فهل يكون للبيئة التنظيمية دور في تعزيز ممارسة وتطبيق التمكين الإداري في شبكة الأقصى الإعلامية؟

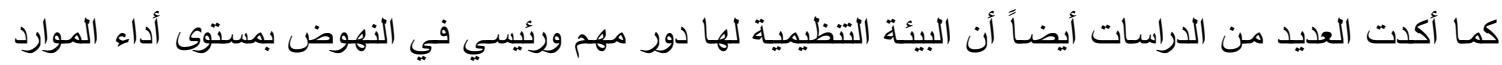

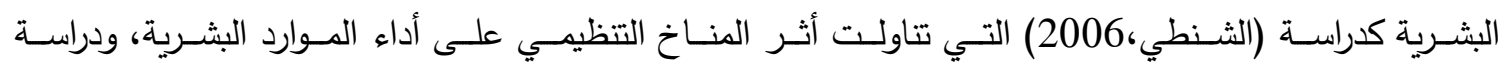
(الأهدل،2011) التي تتاولت أثز البيئة التنظيمية على الأداء الوظيفي للعاملين في شركات الدخان الأردنية، ودراسة

(أبوزيد،2010)التي تتاولت أثر القوة التتظيمية على الإبداع الوظيفي للعاملين في البنوك التجارية الأردنية).

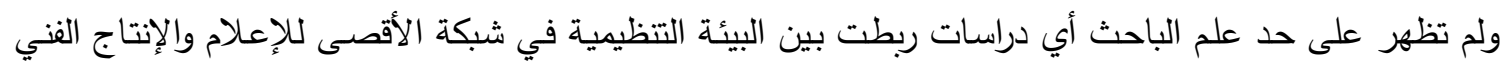

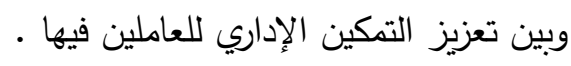
ولكي تتمكن شبكة الأقصى من تحسين أدائها فلا بد من وجود بعض الإدين العوامل التي تساعدها على تحقيق أهدافها

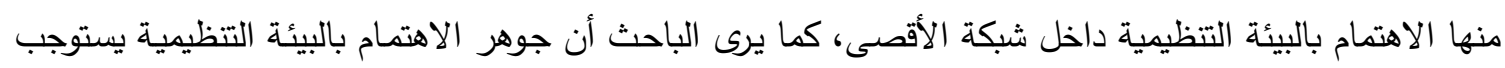

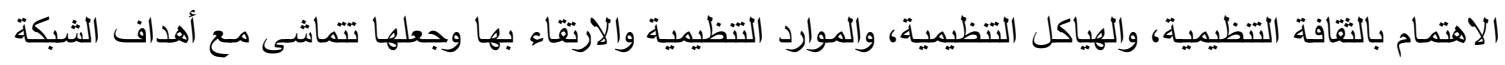
وأهداف الموظفين على حد سواء، لكي تستطيع أن تواكب التطور العلمي في استخدام المفاهيم الإدارية المعاصرة

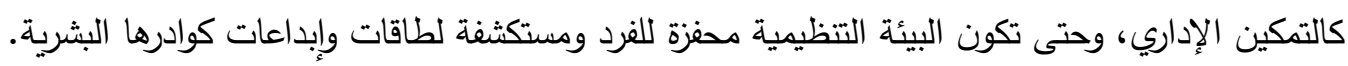
كما يرى الباحث أن هنالك دوراً مهماً يقوم به المديرون في شبكة الأقصى الإدية الإعلامية وما توفره لهم البيئية التتظيمية

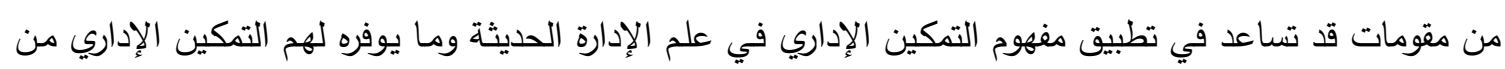


ممارسات إدارية وصلاحيات يستطيعون من خلالها اتخاذ القرارات المناسبة لمعالجة الكثير من المشكلات الإدارية والفنية للارتقاء بأداء مؤسساتها. وخلاصسة القول أنه من خـلال عمل الباحث في شبكة الأقصى الإعلامية فقد نبعت مشكلة الدراسـة من إحساسـه بأهمية دراسة البيئة التتظيمية ودورها في تعزيز التمكين الإداري في شبكة الأقصى الإعلامية كمفهوم إداري حديث

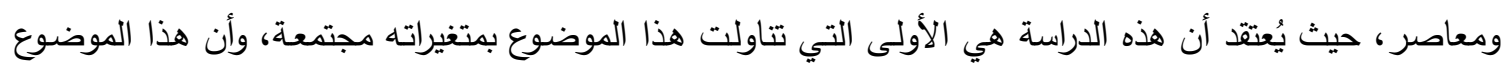

جدير بالبحث حيث أنه من المتوقع أن يمثل خطوة في طريق تطوير أداء المديرين في كافة أفرع شبكة الأقصى لأصى لـ الإعلام والإنتاج الفني. وفي ضوء ما سبق يمكن تلخيص مشكلة الدراسة في السؤال التالي: ما دور البيئية التتظيمية في تعزيز التمكين الإداري في شبكة الأقصى للإعلام والإنتاج الفني؟ أسئلة الاراسة: ويتفرع عن السؤال الرئيس الأسئلة الفرعية التالية:

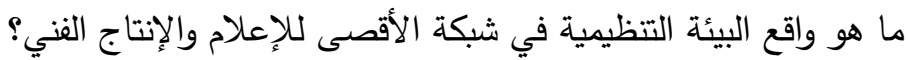

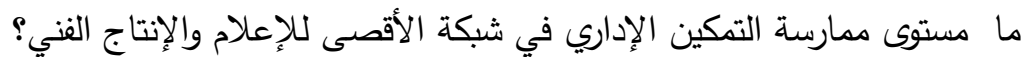

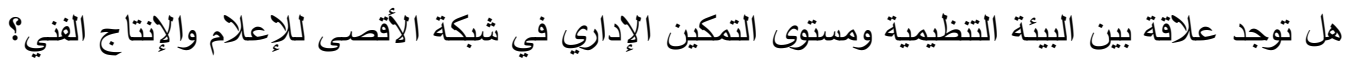

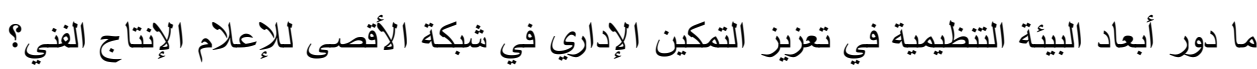

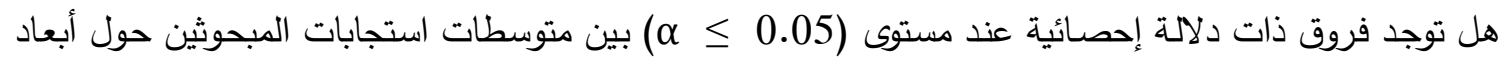
البيئة التنظيمية تُعزى للمتغيرات الديمغرافية(العمر، الجنس، المؤهل العلمي، المستوى الوظيفي، سنوات الخبرة،

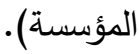
هل توجد فروق ذات دلالة إحصائية عند مستوى (20.05 م) في استجابة المبحوثين حول دور البيئة التظظيمية

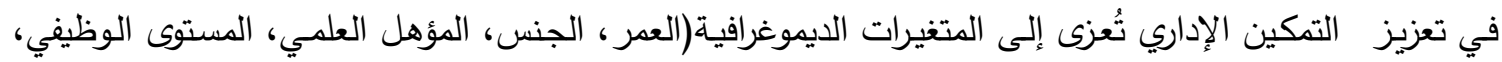
سنوات الخبرة، نوع المؤسسة).

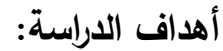

هدفت الدراسـة إلـى التعـرف على دور البيئة التظظيميـة بأبعادهـا (الثقافـة التتظيميـة، والهيكل التتظيمي، والمـوارد التنظيمية) ودورها في تعزيز التمكين الإداري للعاملين في شبكة الأقصى للإعلام والإنتاج الفني وانسجاماً مع أسئلة الدراسة فإن الدراسة الحالية تسعى لتحقيق الأهداف التالية: 1. التعرف على واقع البيئة التظيمية في شبكة الأقصى للإعلام والإنتاج الفني. 2. التعرف على مستوى ممارسة التمكين الإداري في شبكة الأقصى. 3. تحديد مستوى ممارسة التمكين الإداري في شبكة الأقصى للإعلام والإنتاج الفني. 4. التعرف على العلاقة بين البيئة التنظيمية ومستوى التمكين الإداري في شبكة الأقصى للإعلام والإنتاج الفني. 5. الكثـــ عـن الفـروق فـي وجهـات نظـر المبحـوثين حـول أبعـاد البيئـة التتظيميــة تُعـزى للمتغيـرات الديمغرافية(العمر ، الجنس، المؤهل العلمي، المستوى الوظيفي، سنوات الخبرة، المؤسسة).

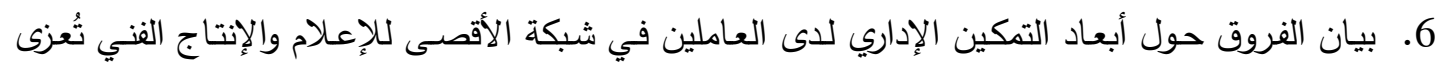

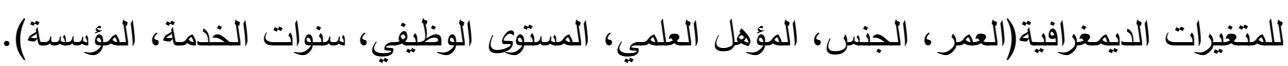


7. التوصل إلى نتائج وتوصيات من شأنها أن تساهم في تعزيز التمكين الإداري للعاملين في شبكة الأقصى

$$
\text { للإِعلام والإنتاج الفني. }
$$

أهمية الاراسة:

يستلهم الباحثث أهميـة هذه الدراسـة مـن العبارة التي تقول" إن مزيــاً مـن التمكين يـؤدي إلـى مزيـاٍ مـن النجـاح

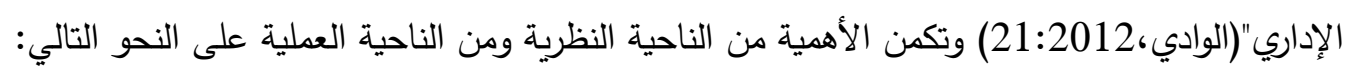

أولاً: من الناحية النظرية:

تكمن أهمية موضوع الدراسـة المتعلق بالدور الذي تلعبه البيئة التظظيمية في تعزيز التمكين الإداري و قدرة هذه المؤسسة على تطوير ذاتها وتحسين عملها حيث يعتبر مفهوم البيئة التظظيمية وكذلك التمكين الإداري من المفاهيم الحديثة والهامة في عصرنا الحالي، وعليه فإن الدراسة الحالية تساير التطور الإداري المنشود وتمثل استجابة للعديد

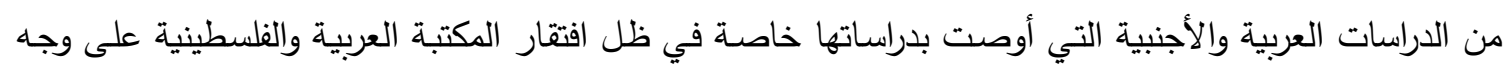
الخصوص لمثل هذا النوع من الدراسات، حيث هناك ندرة واضحة في عدد الأبحاث المنشورة في البيئة العربية

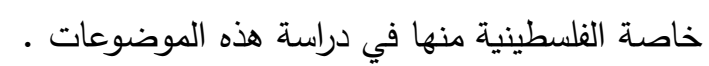
ستضيف هذه الدراسة معلومات جديدة تُعد مرجعاً للباحثين حيث من المتوقع لهذه الدراسة أن تفتح الآفاق لإجراء المزيد من البحوث المستقبلية في هذا المجال المهم.

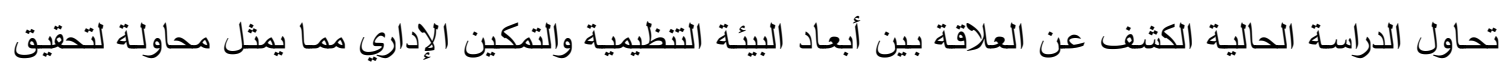
الاستفادة في البيئة الفلسطينية وفي مجال من مجالات العمل الهامة وهو الهجال الإعلامي.

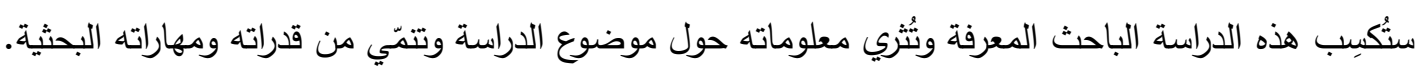
ثانياً: من الناحية العملية: إمكانية الاستفادة من نتائج هذه الدراسة وتقديم النصائح والإرشادات لصناع الناعيات القرار في شبكة الأقصى الإعلامية نحو

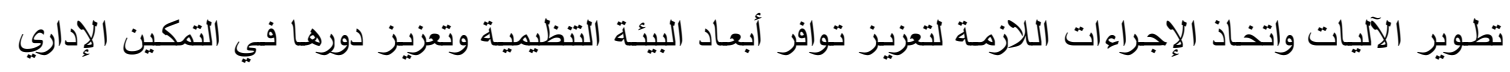
للعاملين بالثبكة واستحداث استراتيجيات جديدة للتعامل مع العاملين فيها.

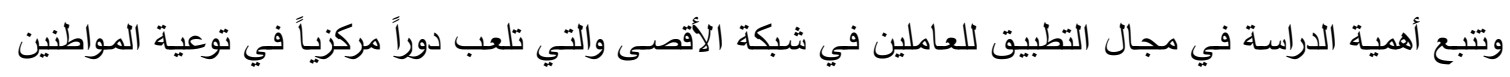

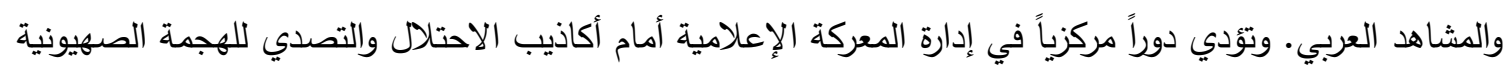
بكافة أنواعها وأشكالها على قطاع غزة. تحفز صانعي القرار على نشر ثقافة التككين الإداري وإبراز دوره في تحفيز القدرات الإبداعية الكامنة لدى العاملين في المؤسسة. تعد هذه الدراسة من الدراسات النادرة في محافظات غزة التي جمعت بين البيئة التنظيمية والتمكين الإداري في شبكة الأقصى الإعلامية. الأهمية للباحث: الباحث يعمل في شبكة الأقصى الإعلامية ويسعى إلى تطوير النظام الإداري، ويهدف إلى استخدام أفضل الأساليب

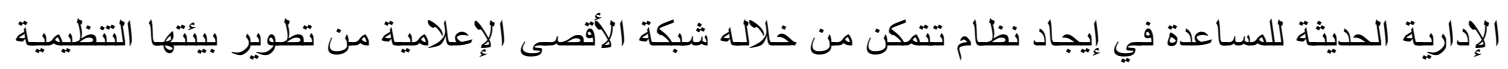

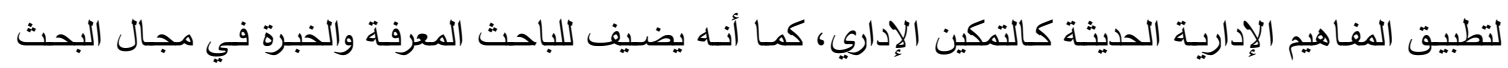
العلمي. 


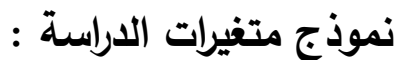

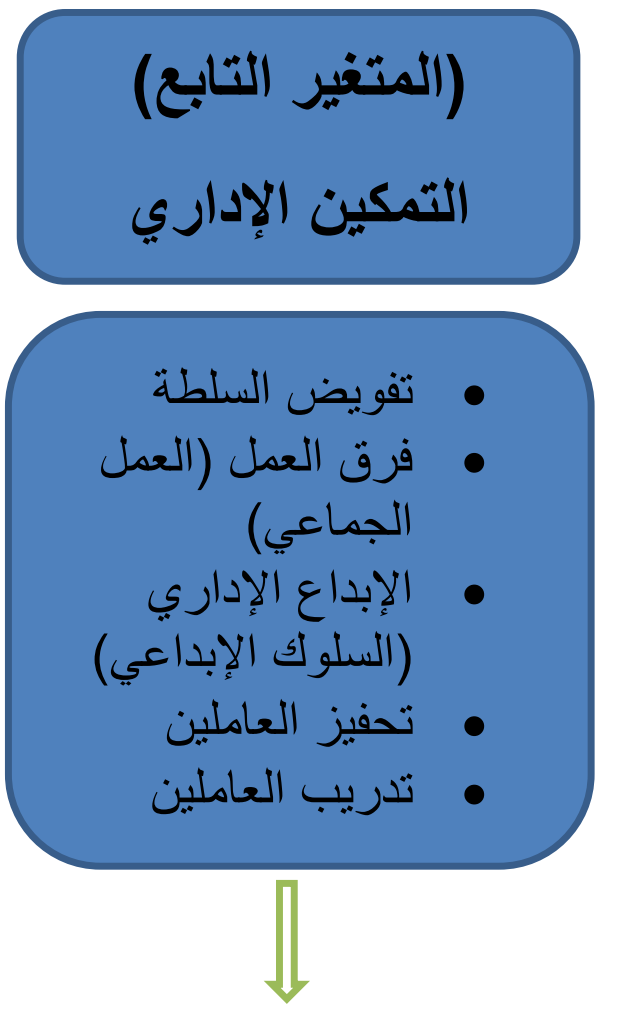

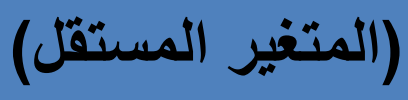

البيئة التنظيمية البية

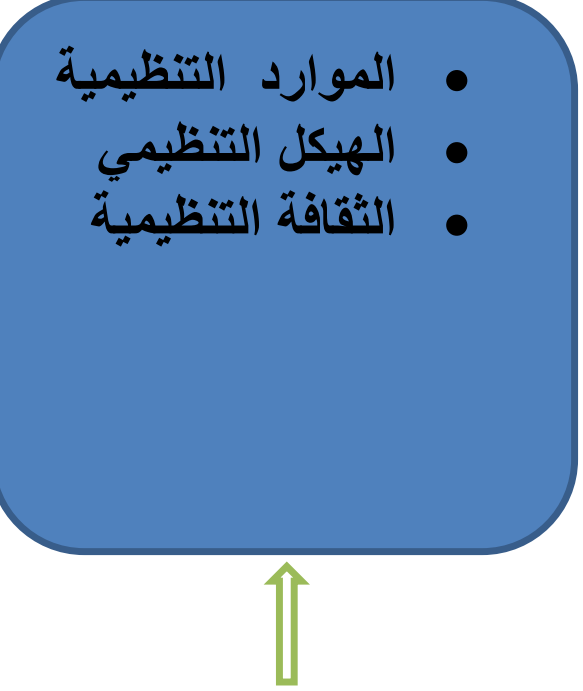

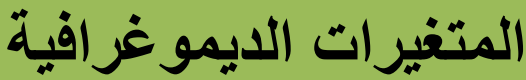

$$
\text { العمر - الجنس - المؤهل العمري - المستوى الوظيفي - سنوات الخبرة - نوع }
$$

$$
\text { شكل رقم(1) متغيرات الدراسة }
$$

المصدر: إعداد الباحث بناء على الأدبيات والدراسات السابقة واعتماداً على (Jones et al.,2004)

للمتغير المستقل (البيئة التتظيمية).

$$
\text { فرضيات الدراسة : }
$$

لكي يتمكن الباحث من الإجابة على أسئلة الدراسة وتحقيق أهداف الدراسة فقد تم تطوير عدد من الفرضيات وهي كالتالي:

الفرضية الرئيسـة الأولـى: توجد علاقة ذات دلالمة إحصـائية عند مستوى (150.05ه) بين أبعاد البيئة التتظيمية ومستوى التمكين الإداري لدى المدراء العامين ومدراء الدوائر ورؤساء الأقسام في شبكة الأقصى للإِعلام والإنتاج 
ويشتق من الفرضية الرئيسة الأولى الفروض التالية:

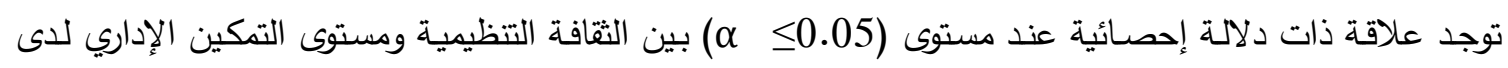
العاملين في الوظائف الإشرافية في شبكة الأقصى للإعلام والإنتاج الفني.

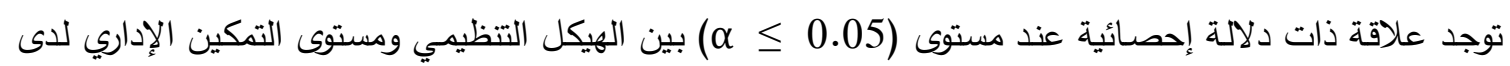
العاملين في الوظائف الإشرافية في شبكة الأقصى للإعلام والإنتاج الفني.

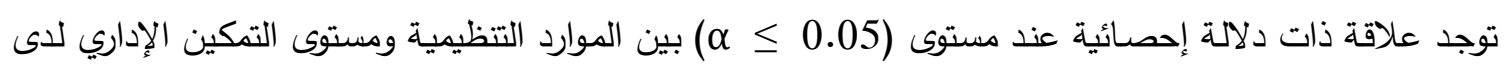
العاملين في الوظائف الإشرافية في شبكة الأقصى للإعلام والإنتاج الفني.

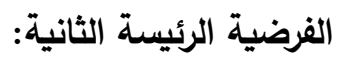

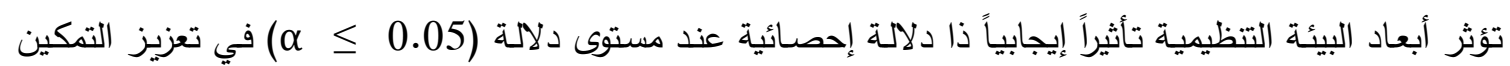
الإداري للعاملين في شبكة الأقصى للإعلام والإنتاج الفني.

الاراسات السابقة

تعتبر الدراسات السابقة الركيزة الأساسية التي يعتمد عليها الباحث من أجل الاسترشاد بها في تصميم

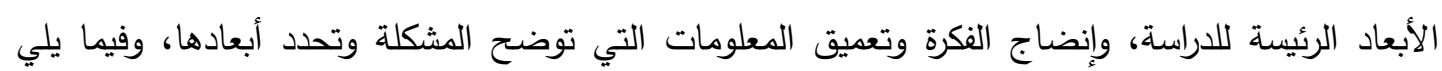
مجموعة من الدراسات البحثية التي ارتبطت بهذا المفهوم للوقوف على أهم المشكلات والقضايا التي تتاولتها

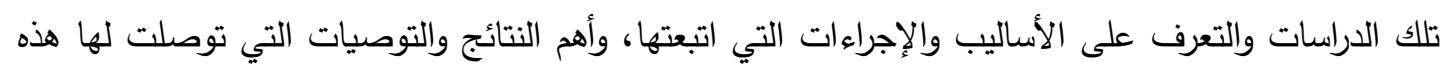

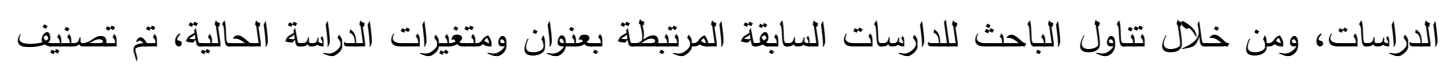
الدراسات إلى ثلاث مجموعات رئيسية وهي ( فلسطينية - عربية - أجنبية) لكل متغير من متغيرات الدراسة وهي(البيئة التنظيمية، والتمكين الإداري) وتثتمل كل منهما على (عنوان وأهدف الدراسة، أهم النتائج والتوصيات التي توصلت إليها الدراسات) وهي مرتبة حسب التسلسل الزمني من الأحدث إلى الأقدم على النحو التالي:

\section{الاراسات الفلسطينية التي ركزت على البيئة التنظيمية}

- - دراسة (فرحات،2017) بعنوان: المناخ التنظيمي وعلاقته بالاتزان الانفعالي لاى العاملين في

الإدارة العامة للصحة النفسية.

هدفت الدراسة إلى التعرف على المناخ التظظيمي وعلاقته بالاتزان الانفعالي لاى العاملين بالإدارة العامة

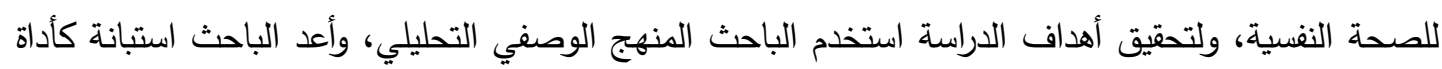

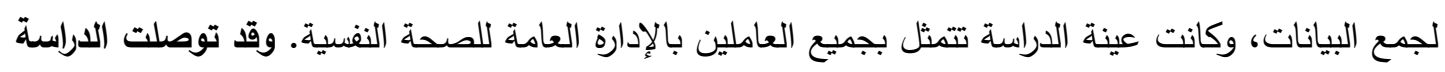

إلى عدد من النتائج أهمها:

مستوى توفر المناخ التنظيمي في الإدارة العامة للصحة النفسية جاءت بدرجة متوسطة.

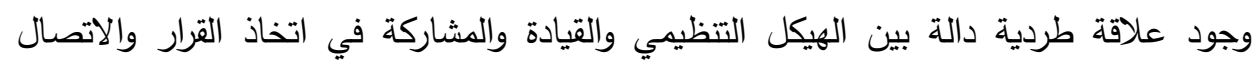

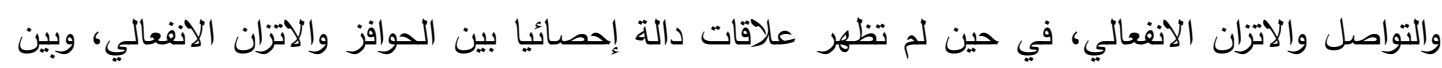

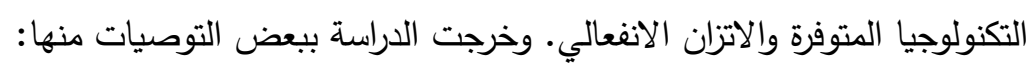
ضرورة إعداد هيكل تتظيمي مرن ومناسب لطبيعة العمل النفسي. 
- - مأهية إعداد نظام حوافز مناسب لكافة العاملين بحيث تمنح الحوافز على أساس نتائج تقييم

2- دراسة (أبو شعير، 2017) بعوان:" إدارة الموارد البشرية وعلاقتها بالأمن الوظيفي- دراسة

مقارنة بين المدارس الحكومية ووكالة الغوث الدولية بغزة"

هدفت الدراسة للتعرف إلى العلاقة بين إدارة الموارد البشرية والأمن الوظيفي في كلٍ من المدارس

37 الحكومية ومدارس وكالة الغوث بغزة، واعتمد الباحث منهج المقارنة التحليلي، واستخدم الباحث الاستبانة كأداة لجمع البيانات. وقد توصلت الاراسة إلى عدد من النتائج أهمها: واقع إدارة الموارد البشرية في المدارس الحكومية بلغ(67.8\%) بينما بلغ بمدارس وكالة الغوث

الدولية بغزة (75\%).

- - توجد علاقة ذات دلالة إحصائية بين إدارة الموارد البشرية وعلاقتها بالأمن الوظيفي في كلٍ من

المدارس الحكومية ومدارس وكالة الغوث الدولية. وكانت أهم التوصيات التي أوصت بها الدارة الداسة:

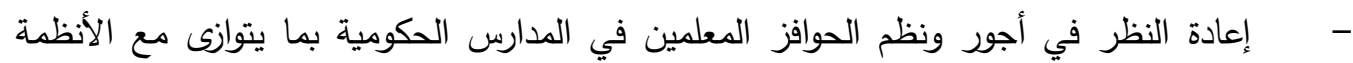

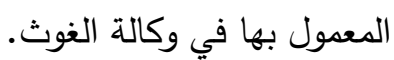

- - تفعيل نتائج الأداء واستعمالها في عملية الترقيات أو الجزاءات.

- - - ماستثمار الطارقات والقدرات الكامنة لدى الموظفين بإشراكهم في عملية اتخاذ القرارات.

3- دراسة (نصار، 2016) بعنوان: دور بيئة العمل في الالتزام التنظيمي من وجهة نظر العاملين

في الجامعات الفلسطينية.

هدفت الدراسة التعرف على دور بيئة العمل في الالتزام التنظيمي من وجهة نظر العاملين الإداريين في

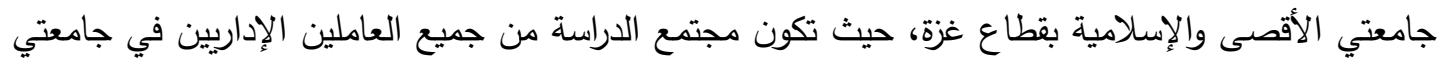

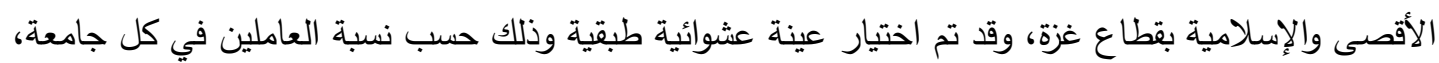

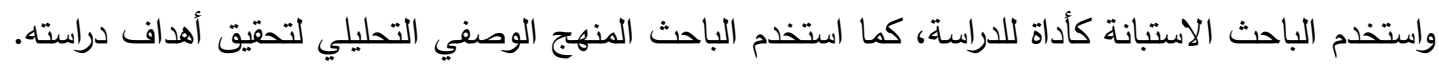
ومن أهم النتائج التي توصل إليها ما يلي:

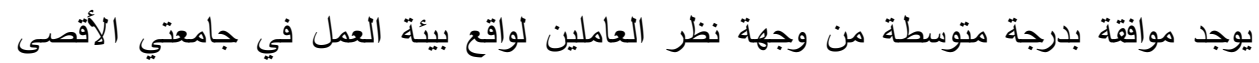
والإسلامية بقطاع غزة.

يوجد موافقة بدرجة كبيرة من وجهة نظر العاملين لمستوى الالتزام التظيمي في جامعتي

الأقصى والإسلامية. وخرجت الاراسة ببعض التوصيات منها:

دعم الجامعة العاملين خارج بيئة العمل، بتقديم خدمات متتوعة:(مالية، قانونية، استثارية،....).

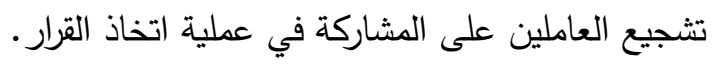

4- دراسة (عودة،2016) بعنوان: دور القيادة الخادمة في تحسين مستوى البيئة التظيمية بوزارة الاخلية والأمن الوطني.

هدفت الدراسة التعرف على دور القيادة الخادمة في تحسين مستوى البيئة التظظيمية بوزارة الداخلية والأمن الوطني- الثق العسكري بقطاع غزة، حيث تكون مجتمع الدارسة من العاملين في الوظائف 
الإشرافية(رئيس قسم حتى مدير عام جهاز) وقد بلغت عينة الدراسة(240)موظفاً من العاملين في الوظائف

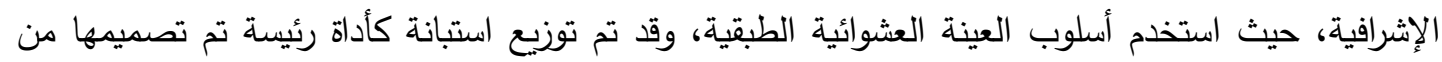
قبل الباحث، وقد استخدم الباحث المنهج الوصفي التحليلي لتحقيق أهداف دراسته. ومن أهم النتائج التي تُّن توصل إليها ما يلي:

يؤثر المتغير المستقل(القيادة الخادمة) في المتغير التابع(البيئة التنظيمية). توجد علاقة ذات دلالة إحصائية بين دور القيادة الخادمة وتحسين مستوى البيئة التظيمية. وخرجت الاراسة ببعض التوصيات منها:

زيادة الاهتمام بالمرؤوسين من خلال تطوير قدراتهم في العمل والاهتمام بحاجاتهم الثخصية.

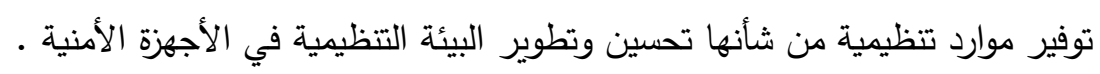

\section{الاراسات العربية التي ركزت على البيئة التنظيمية}

- 1 - دراسة ( صورية،2015) بعنوان: دور البيئة التنظيمية في زيادة فعالية تطبيق عمليات إدارة

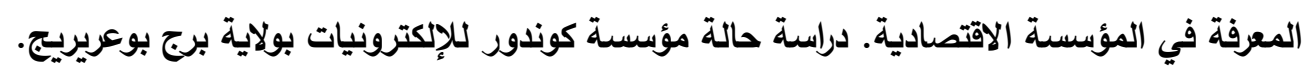
هدفت الدراسة إلى التعرف على مدى توفر البيئة التظيمية والمساعدة على زيادة فعالية تطبيق عمليات إدارة المعرفة في مؤسسة كوندور، واختار الباحث مؤسسة كوندور لإنتاج الإكترونيات كمجتمع للدراسة،

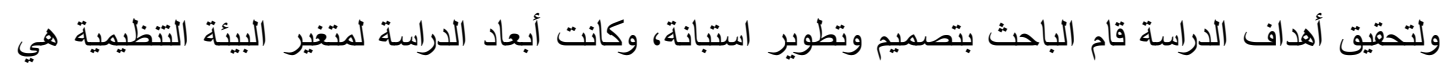

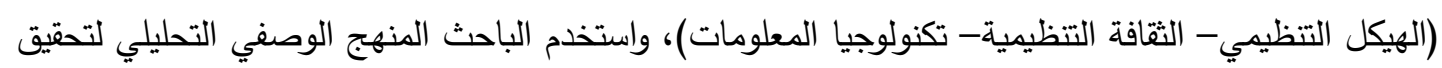
أهداف دراسته. وقد تمثلت أهم نتائج الاراسة بالآتي:

وجود علاقة ارتباطية معنوية بين توفر البيئة التنظيمية وفعالية تطبيق إدارة المعرفة، فالمنظمة التي توفر المناخ المناسب لتطبيق معارفها واستخدامها في حياتها التتظيمية تكون أكثر فاعلية وقدرة على وفئل تحقيق أهدافها من المؤسسات الاخرى.

إن أفراد عينة البحث متفقين في الرأي حول أهمية توفير البيئة المناسبة وكل المستلزمات التي

تضمن تطبيق عمليات ادارة المعرفة بفعالية وكفاءة من خلال وجود هيكل تتظيمي ونظام إداري مرن يجعل الجرل

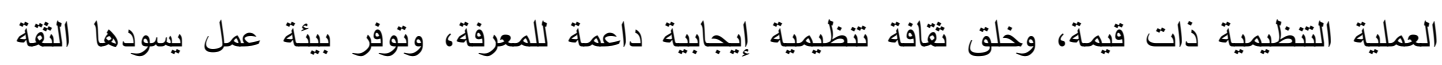

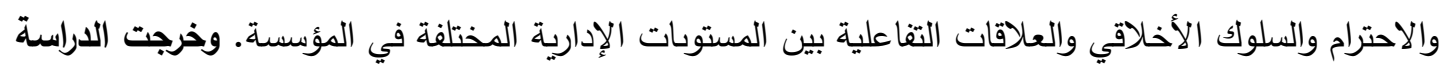

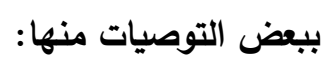
- - أن تعمل المؤسسة على توفير الموارد البشرية اللذين تقع على عاتقهم مسؤولية القيام بالنشاطات اللازمة لتوليد المعرفة وحفظها وتوزيعها.

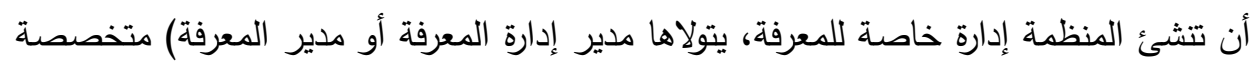
في تطوير أنشطة إدارة المعرفة والعمل على متابعة تطبيق عملياتها.

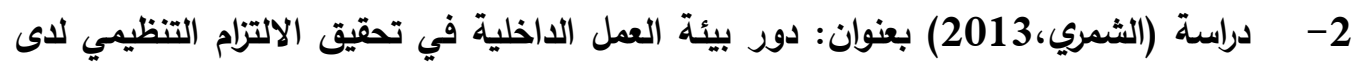
منسوبي قيادة حرس الحدود بمنطقة الحدود الثمالية. 
هدفت الدراسة إلى التعرف على دور بيئة العمل الداخلية في تحقيق الالتزام التنظيمي لدى منسوبي قيادة حرس الحدود بمنطقة الحدود الثمالية، حيث تثكل مجتمع الدراسة من قيادة حرس الحدود، وبلغ حجم العينة

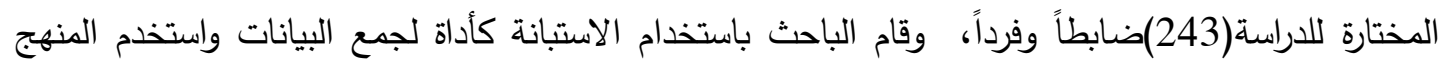
الوصفي التحليلي لتحقيق أهداف الدراسة، وتوصلت الاراسة إلى عدة نتائج أهمها: - - - أهم الخصائص المهمة لبيئة العمل الداخلية هي العمل بروح الفريق في مواجهة أعباء ومهام حرس الحدود، والتزام العاملين بأنظمة وتعليمات حرس الحدود.

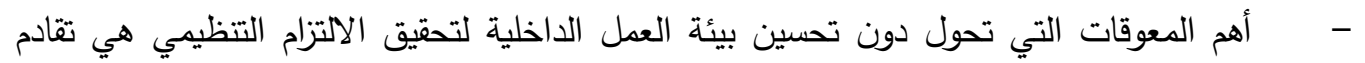

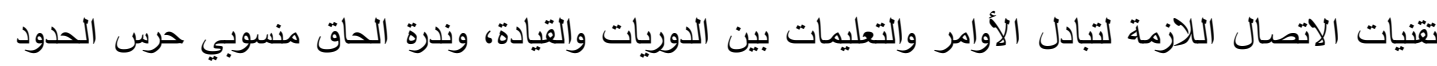

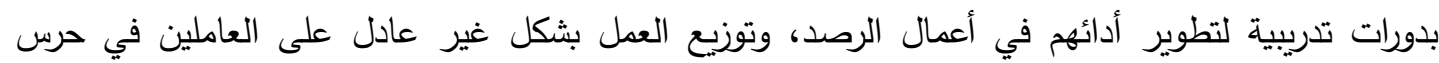
الحدود. وخرجت الدراسة ببعض التوصيات منها: الاستمرار في تعزيز مستوبات الالتزام التنظيمي. الاستمرار في تعزيز بيئة العمل الداخلية الإيجابية.

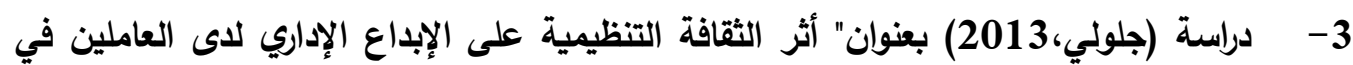
مؤسسات التعليم العالي الجزائرية". هدفت الدراسة إلى التعرف على اتجاهات العاملين في جامعة بسكرة في الجزائر نحو مستوى الثقافة

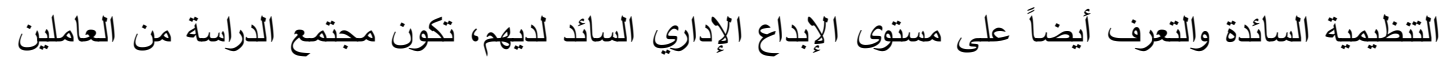

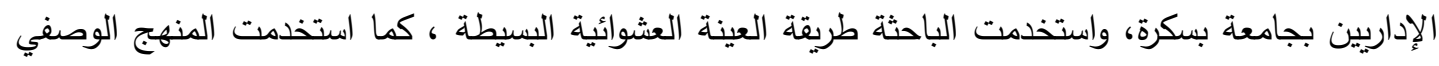
التحليلي للوصول إلى نتائج الدراسة. وتوصلت الدراسة إلى عدة نتائج أهمها: - - ماء مستوى الإبداع الإداري لاى العاملين بالجامعة بمستوى مرتفع، وتبين وجود أثر ذو دلالة إحصائية بأبعادها المختلفة في الإبداع الإداري لاى العادئ الإدين. وجود فروق ذات دلالة إحصائية في اتجاهات المفحوصين حول مستوى الإبداع الإداري لإى لإى الإدي

العاملين تعزى للمتغيرات الديمغرافية. وخرجت الدراسة ببعض التوصيات منها: - - ملى إدارة الجامعة تشجيع حالة التنافس وتكريم المبدعين. - - - - - ترسيخ النهج الديمقراطي بين الدرسين والطلبة العاملين.

4- دراسة(محمد، 2012) الثقافة التنظيمية وعلاقتها بالإبداع الإداري للقيادات الإدارية بجامعة أسيوط. هدفت الدراسة إلى تحديد العلاقة بين الثقافة التتظيمية السائدة ومستوى الإبداع الإداري للقيادات الإدارية

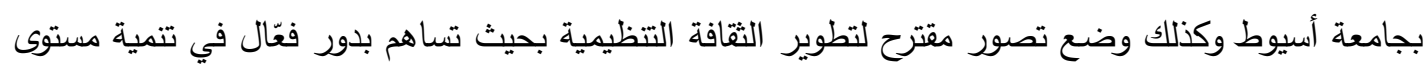

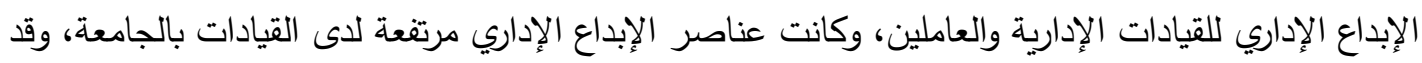

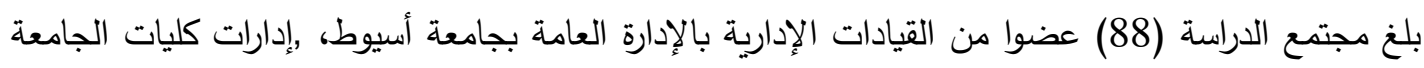

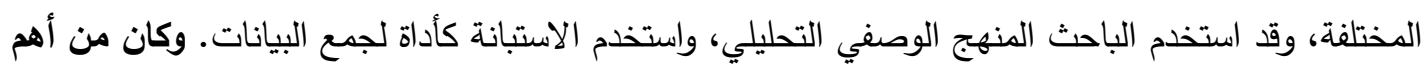

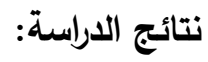


توفر القدرات الإبداعية بدرجة عالية لاى القيادات الإدارية بالجامعة وكان ذلك يعزى إلى توفر

البيئة والمناخ الجامعي الذي يساعد على نمو قدرات. وكان من أهم توصيات الدراسة:

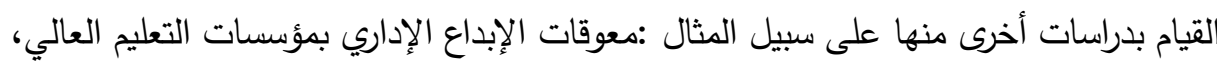

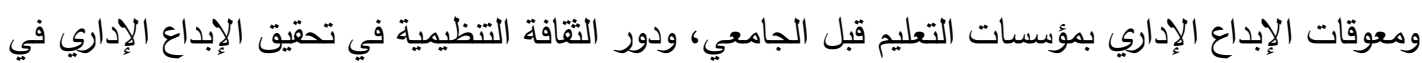

المدرسة الإبتدائية.

5- دراسة (المشوط، 2011) بعنوان :أثر بيئة العمل على الإبداع الإداري "دراسة تطبيقية على

أكاديمية سعد العبدالله للعلوم الأمنية في دولة الكويت.

هدفت الدراسة إلى التعرف على أثر بيئة العمل على الإبداع الإداري في أكاديمية سعد العبد الله للعلوم

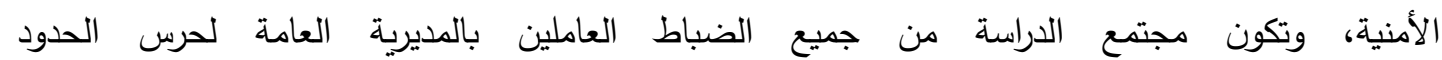

وعددهم(550)ضابطاً، و قام الباحث بتصميم استبانة لجمع المعلومات، واستخدم الباحث المنهج الوصفي

التحليلي لتحقيق أهداف الدراسة. وتوصلت الدراسة إلى عدة نتائج أهمها:

وجود تأثير ذي دلالة معنوية للهيكل التنظيمي على الإبداع الإداري(السلوك الإبداعي، والقدرات التهات

الإبداعية).

وجود تأثير ذي دلالة معنوية للمشاركة في اتخاذ القرارات على الإبداع الإداري (السلوك

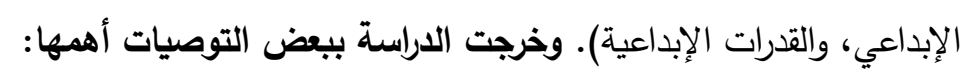

- - - الاهتمام بنشر روح الفريق بين العاملين في أكاديمية سعد العبد الله للعلوم الأمنية في دولة

الاستعانة بالخبراء والمتخصصين في مجال التطوير التظيمي لتحسين واقع التطوير التظيمي

بالمديرية.

3-3: الدراسات الأجنبية التي ركزت على اليئة التنظيمية

(Zamani \& karimi ,2016) بعنوان:

العلاقة بين المناخ التظيمي والصمت التنظيمي لاى الموظفين الإداريين في وزارة التعليم"، إيران.

The Relationship between Organizational Silence of dminstrative

staff in Education Department.

هدفت الدراسة إلى تحديد العلاقة بين المناخ التظظيمي والصمت التظيمي للموظفين الإداريين في وزارة

التربية والتعليم بأصفهان واستخدمت المنهج الوصفي الارتباطي، وتم اختيار عينة بلغت(220)موظفاً من

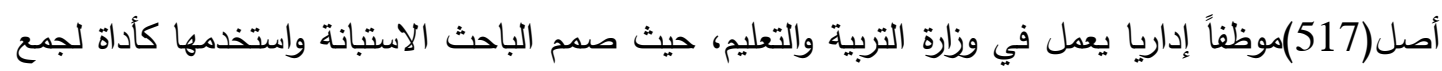
البيانات. وخلصت الاراسة إلى مجموعة من النتائج أهمها:

وجود علاقة ارتباطية سالبة بين المناخ التنظيمي والصمت التتظيمي، وعلاقة سالبة بين أبعاد

المناخ التظيمي والصمت الوظيفي

- - مأشارت نتائج الانحدار المتعدد أنه يمكن التتبؤ بالصدت التتظيمي وإجراءات العمل وأهداف

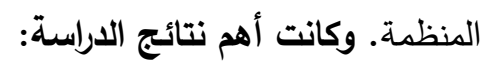

عقد ورشات عمل للموظفين من أجل تطوير مهارات التواصل لديهم. 
- - - الترحيب وتثجيع الأفكار البنائية والمقترحات الإبداعية من خلال نظام تثجيعي مناسب.

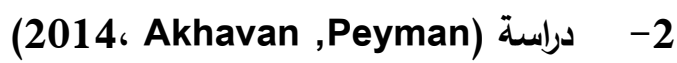

بعنوان : تأثير الثقافة التظيمية ونمط القيادة على إدارة المعرفة في منظمات بحثية مختارة. The Effect Of organizational culture and Leadership Style on -

Knowledge Management in Selected Research organizations

هدف الدراسة إلى التعرف على أثر الثقافة التتظيمية والنمط القيادي على المعرفة الإدارية وطبقت على $\quad 41$ عينة مكونة من (224) موظف من 4 مراكز بحوث مختارة في اندونيسيا, , وتمثل المتغير المستقل بالثقافة التتظيمية والنمط القيادي ,واشتملت الثقافة التتظيمية على أربعة أبعاد (ثقافة المشاركة, والابتكار , العقلانية, الاستقرار) والنمط القيادي على بعدين (النمط الديمقراطي ,والنمط الأوتقراطي), أما المتغير التابع فهو المعرفة الإدارية اشتمل على أربعة أبعاد (الإبداع المعرفي, التتظيم ,المشاركة, التطبيق) واستخدم الباحث الاستبانة كأداة

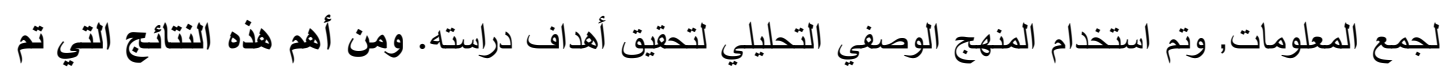
التوصيل إليها كالتالي: - الثقافة التتظيمية السائدة والنمط القيادي لهم تأثير واضح على أبعاد عمليات المعرفة الإدارية حيث وجد أن ثقافة المشاركة لها تأثير إيجابي على عمليات المعرفة الإدارية. - وأظهرت أن ثقافة الاستقرار لها علاقة إيجابية موجبة بالمعرفة الإدارية.

-3 - مارسة (Rankouh, A. \& Poor,2013) بعنوان " دراسة العلاقة بين الثقافة التنظيمية وإبداع المحاضرين".

Examine the Relationship between Organizational Culture and Creativity of Lecturers. Universal Journal of Management and Social Sciences, هدفت الدراسة إلى التعرف على العلاقة بين الثقافة التنظيمية وتثجيع الإبداع لدى المحاضرين

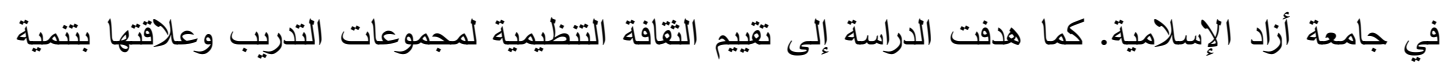
إبداع المحاضرين، ولقد استخدم الباحثان المنهج الوصفي التحليلي، حيث تم استخدام الاستبانة كأداة للدراسة.وأهم نتائج الدراسة:

- وجود علاقة مباشرة بين الثقافة التتظيمية وتعزيز إبداع المحاضرين، كما بينت الدراسة وجود اختلاف بين ثقافة الكليات وفروع الجامعة من حيث الكليات وفروع الجامعة من حيث هناك كليات تميزت بتوفير مستوى عالٍ من الثقافة التي تدعم إبداع المحاضرين، وأن فروع الجامعة لديها مستوى من الثقافة. وتوصلت الدراسات

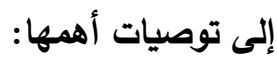

جعل المدراء والمحاضرين ذو علاقة بالثقافة التتظيمية ومكوناتها من خلال المجالات، وأوراق العمل، والمؤتمرات.

تفويض الصلاحيات والمسؤوليات بالتساوي لمدراء الدوائر وللمحاضرين وتزويدهم بتغذية راجعة ملائمة وفي الوقت المناسب حول تقدم أنشطة العمل. الاراسات الفلسطينية التي ركزت على التمكين الإداري

- 1 - دراسة (قويدر،2017) درجة ممارسة القيادات الأكاديمية في الجامعات الفلسطينية بمحافظات غزة للتمكين الإداري وعلاقته بالالتزام التظظيمي لاى أعضاء الهيئة التدريسية. 
هدفت الدراسة إلى التعرف على درجة ممارسة القيادات الأكاديمية في الجامعات الفلسطينية بمحافظات غزة للتمكين الإداري وعلاقته بالالتزام التظظيمي لدى أعضاء الهيئة التدريسية، واستخدم الباحث المنهج الوصفي لإديه التحليلي، وتكونت عينة الدراسة من جميع العمداء، ونوابهم، ورؤساء الأقسام في الجامعة الإسلامية، وجامعة لإداء الأقصى والبالغ عددهم (170)عضواً وتم استخدام أسلوب المسح الثامل، واستخدم الباحث الاستبانة كأداة

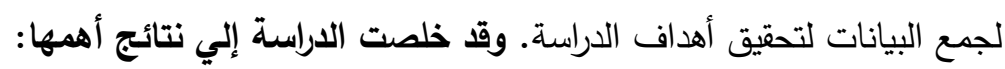
درجة ممارسة القيادات الأكاديمية في الجامعات الفلسطينية بمحافظات غزة للتكين الإداري

جاءت بدرجة موافقة كبيرة .

وجود علاقة ارتباطية موجبة (طردية) بين درجة ممارسة القيادات الأكاديمية في الجامعات الفلسطينية للتمكين الإداري، ومستوى تحقيق الالتزام التظيمي لأعضاء الهيئة التذريسية .وقد أوصت الدادية الدراسة بالعديد من التوصيات أهمها:

اعتماد التمكين أسلوباً وفلسفةً في المؤسسات التعليمية، والعمل على تعزيزه لتعيق الوعي بهذا الجانب، مع انفتاح الإدارة ورفع الحواجز والفواصل الإدارية والرئاسية. تبني أسلوب العمل الجماعي، ودعم وجود فرق العمل في الجامعات، والتشجيع على تثكيلها، لأنها من أفضل الوسائل للوصول إلى أفضل النتائج للأهداف المراد تحقيقها. 2- دراسة (أبو ناموس،2016) بعنوان: فاعلية القيادة وعلاقتها بالسلوك الإبداعي لاى العاملين بالخدمات الطبية العسكربة في محافظات غزة.

هدفت الدراسة إلى التعرف على مستوى فاعلية القيادة وعلاقتها بالسلوك الإبداعي لاى العاملين بالخدمات الطبية العسكرية في محافظات غزة، وتكونت عينة الدراسة من العاملين في مؤسسة الخدمات الطبية العسكرية، واستخدمت الباحثة الاستبانة كأداة للدراس، كما استخدمت المنهج الوصفي التحليلي كمنهج لتحقيق أهداف الدراسة. وقد خلصت الاراسة إلي نتائج أهمها: مستوى السلوك الإبداعي لاى العاملين بالخدمات الطبية العسكرية جاء بدرجة متوسطة. مستوى حل المشكلات بطريقة إبداعية ومميزة لاى العاملين جاء بدرجة متوسطة.

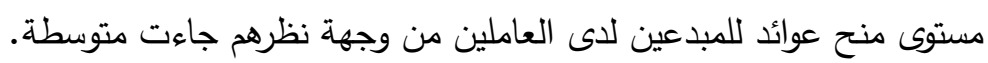
وخرجت الاراسة ببعض التوصيات منها: ضرورة تتمية قدرات مؤسسة الخدمات الطبية وتطويرهم وحثهم على تحسين أدائهم الإداري والإنساني. تتمية وتطوير السلوك الإبداعي من خلال تتمية القدرة على حل المشكلات بالطرق الإبداعية والنقد وتنمية القدرة على التواصل الاجتماعي داخل المؤسسة 3- دراسة (عبيدة،2016) بعنوان: العلاقة بين المناخ التنظيمي والسلوك الإبداعي

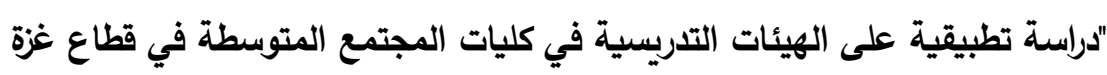

هدفت الدراسة إلى التعرف على العلاقة بين المناخ التظظيمي والسلوك الإبداعي لأعضاء الهيئات التدريسية في كليات المجتمع المتوسطة في قطاع غزة، وتكون مجتمع الدراسة من جميع أعضاء الهيئات 
التدريسية في كليات المجتمع المتوسطة التي تم اختيارها لإجراء الدراسة والبالغ عددهم(442)عضواً، أما عينة

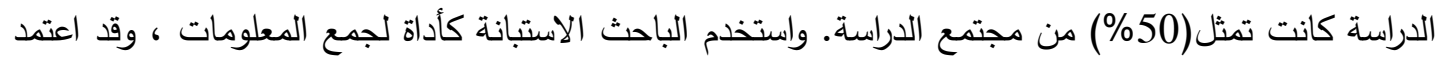

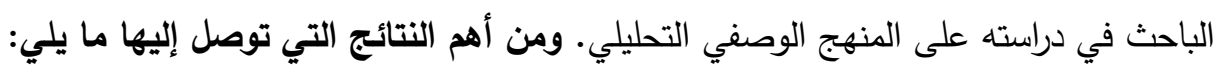
يتصف الهيكل التظيمي في كليات المجتمع المتوسطة في قطاع غزة بالمرونة التي تساعد على الإبداع الإداري لدى العاملين.

تتظر الإدارة العليا في كليات المجتمع المتوسطة إلى الإبداع على أنه مورد ينبغي الاستثمار فيه.

$$
\text { وقت أوصت الاراسة بالعديد من التوصيات أهمها: }
$$

العمل على تعزيز الجوانب الإيجابية للمناخ التنظيمي ومعالجة الجوانب السلبية، لما لذلك من

$$
\text { دور كبير في تعزيز السلوك الإبداعي لدى العاملين. }
$$

- - - تبني الإدارة للأفكار الإبداعية لدى العاملين والعمل على توفير الدعم المادي والمعنوي للمبدعين.

4- دراسة (الجعبري،2010) بعنوان " واقع تمكين العاملين في الجامعات العامة الفلسطينية

العاملة في الضفة الغربية من وجهة نظر عامليها الإداريين".

هدفت الدراسة إلى التعرف على واقع تمكين العاملين الإدارين في الجامعات العامة الفلسطينية العاملة في الضفة العربية من زاوية التمكين الإداري، واستخدم الباحث المنهج الوصفي التحليلي، وتم استخدام الاستبانة

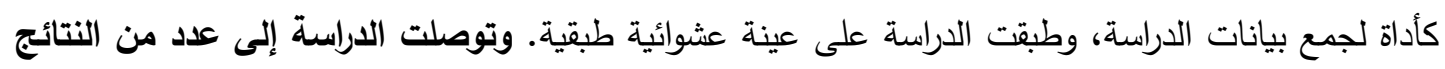
أهمها:

أن واقع التمكين الكلي للعاملين الإداريين في الجامعات العامة الفلسطينية العاملة في الضفة الغربية جاء بدرجة موافقة مرتفعة .

لا توجد فروق في واقع التمكين الكلي للعاملين الإدارين في الجامعات الفلسطينية في الضفة دونة الغربية تعزى لمتغيرات(الجنس، العمر ، المؤهل العلمي) بينما وجدت فروق لباقي المتغيرات الديمغرافية للدراسة. وخرجت الاراسة بعدة توصيات أهمها: ضرورة تثخيص معيقات تطبيق التمكين الإداري. العمل على تقوية درجة تمكين العاملين من خلال إعادة النظر في نظام الحوافز والتركيز على التهلى المكافآت الفردية المرتبطة بمؤشرات الأداء الجيد. 3-5: الدراسات العببية التي ركزت على التمكين الإداري 1 - دراسة (ابن زرعة، 2016م) عناصر الإبداع الإداري لاى قيادات الكليات في جامعة الأميرة نورة بنت عبد الرحمن.

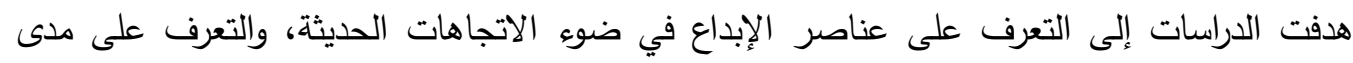

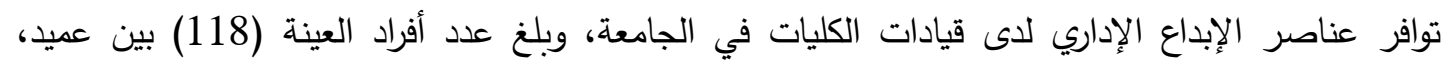

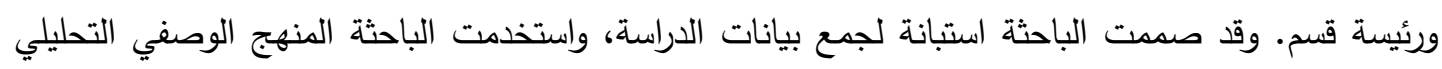
لتحقيق أهداف الدراسة. وكان من أهم نتائج الدراسة: 


$$
\text { أن جميع عناصر الإبداع الإداري متوافرة بدرجة عالية لدى قيادات الكليات. }
$$

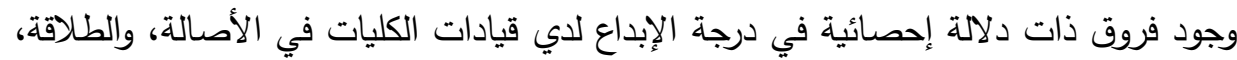

$$
\begin{aligned}
& \text { والحساسية للمشكلات، والخروج عن المألوف تعود لنوع الكلية. } \\
& \text { وخرجت الاراسة بالعديد من التوصيات أهمها: }
\end{aligned}
$$

ضرورة اهتمام القيادات العليا في الجامعة، والاستفادة من توافر عناصر الإبداع الإداري لدى

قيادات الكليات، وتسخيرها ودعمها لصالح النهوض بالعملية التعليمية وتطوير الكليات.

بحث سبل التعاون مع الكليات، وعقد ورش عمل دورات تدريبة لقيادات الكليات الحالية

،والقيادات المستقبلية لتتمية عناصر الإبداع الإداري لدى المهنيين، وضرورة تتمية عناصر الإبداع الإداري لاى أعضاء هيئة التدريس بشكل عام .

2- دراسة (العووادة:2014) العوامل التظظيمية المؤثرة في التفويض الإداري: تصورات الموظفين

$$
\text { (المديرين) في مراكز الوزارات الأردنية. }
$$

هدفت الدراسة للتعرف إلى العوامل التظيمية(الهيكل التتظيمي، النمط الإداري، مهارة ورغبة المرؤوسين في تحمل مسؤوليات جديدة، انسياب المعلومات، ثقافة المنظمة، تقييم الموظفين)المؤثرة في تصورات الموظفين للتفويض الإداري في مراكز الوزارات الأردنية.

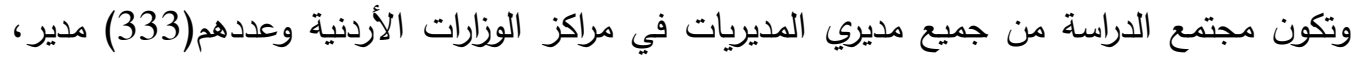

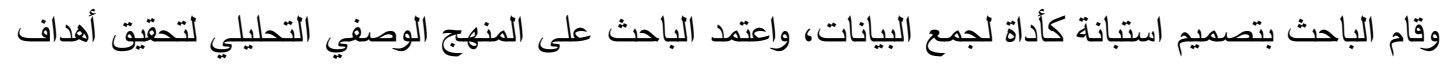
دراسته. وقد تمثلت أهم نتائج الدراسة في التالي:

وجود علاقة ذات دلالة إحصائية بين العوامل التظظيمية(الهيكل التنظيمي، النمط الإداري، مهارة

ورغبة المرؤوسين في تحمل مسؤوليات جديدة، انسياب المعلومات، ثقافة المنظمة، تقييم الموظفين) وتصورات الموظفين نحو التفويض الإداري في مراكز الوزارات الأردنية.

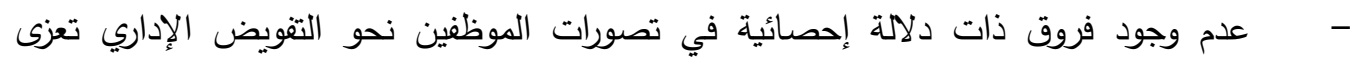

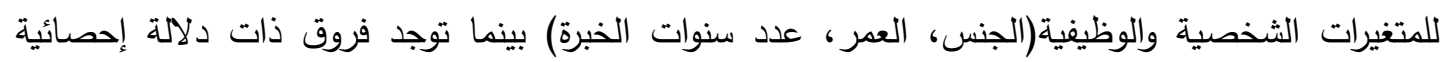
لتصورات الموظفين للعوامل المؤثرة في التقويض الإداري في مراكز الوزارات الأردنية تعزى لمتغير المؤهل العلمي. وخرجت الدراسة ببعض التوصيات منها:

- - ماعمل على تصميم هيكل تنظيمي يساعد في التعويض الإداري وممارسته من قبل المديرين والموظفين باعتبار أن الهيكل التظيمي هو أحد العوامل الرئيسية المؤثرة على تصورات المدراء للتفويض الإدي

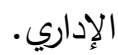

- - - - ملعمل على دراسة وتحليل تقييم الموظفين لعمليات التفويض الإداري واتجاهاتهم نحو عملية التقويض لزيادة حافزيتهم نحو التفويض الإداري. الارلسات الأجنبية التي ركزت على التمكين الإداري 1- دراسة ( AL- Magableh, M. \& Otoum,2015) بعنوان: التمكين الإداري وعلاقته بالسلوك الإبداعي لاى رؤساء أقسام الأكاديمية في كلية العلوم والآداب بجامعة نجران. 
the Administrative Empowerment and its Relationship with the Innovative Behavior among the Head / Coordinators of the Academic Department at the Faculty of Science and Arts.

هدفت الدراسة إلى التعرف على درجة التمكين الإداري وكذلك درجة السلوك الإبداعي بين رؤساء الأقسام الأكاديمية

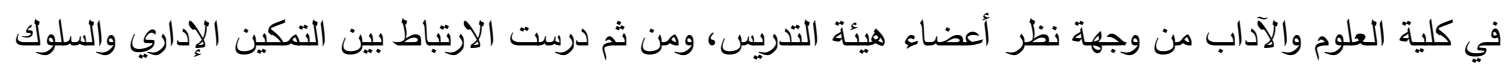
الإبداعي، واستخدم الباحث المنهج الوصفي الارتباطي، وقد صمح استبانة لجمع بيانات الدراسة، وتكونت عينة الدراسة من 120 من أعضاء هيئة التدريس حيث تم اختيارهم عشوائيا. وقد توصلت الدراسة إلى عدة نتائج أهمها:

$$
\text { - وجود درجة متوسطة من التمكين الإداري ودرجة متوسطة من السلوك الإبداعي على حد سواء. }
$$

2 2- دراسة (Touama, 2015) بعنوان: أثر تطبيق استراتيجية التمكين التنظيمي في تعزيز الإبداع

$$
\text { التنظيمي في الجامعات الأردنية. }
$$

هدفت الدراسة إلى التعرف على أثر تطبيق استراتيجية التمكين التتظيمي في تعزيز الإبداع التتظيمي في الجامعات الأردنية، وتكون مجتمع الدراسة من أعضاء هيئة التدريس في جامعة الزرقاء الأردنية ، وقام الباحث باستخدام العئ العينة العينة

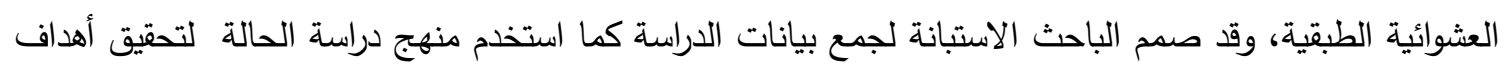

$$
\text { دراسته. وتوصلت الدراسة إلى عدة نتائج أهمها: }
$$

- - توجد علاقة ذات دلالة إحصائية بين أبعاد التمكين الإداري والإبداع التنظيمي في الجامعات الأردنية. - - ميوجد أثر ذو دلالة إحصائية لتطبيق استراتيجية التمكين التظيمية في تعزيز الإبداع التتظيمي .

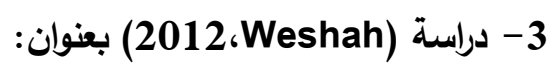

مفهوم التمكين وتفويض السلطة لاى العاملين في المدارس الأردنية والأسترالية " دراسة مقارنة ".

The Perception of Empowerment and Delegation of Authority by Teachers in Australian and Jordanian schools: A comparative study هدفت الدراسة إلى استكثاف التمكين وتفويض السلطة لدى العاملين كما يدركها المعلمون في الددارس الأسترالية والأردنية، حيث تألف مجتمع الدراسة من جميع المدارس التي تتعاون مع الجامعة الأردنية في عمان

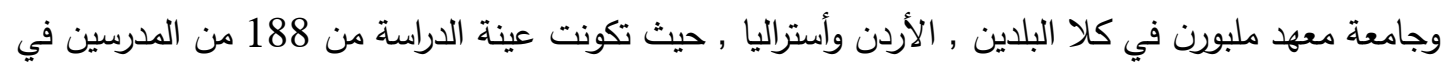

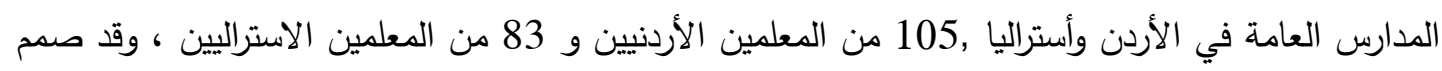
الباحث استبانة كأداة لجمع البيانات، كما استخدم المنهج الوصفي التحليلي لتحقيق أهداف دراسته.

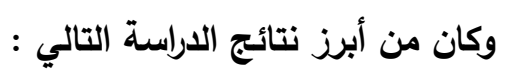

- مستوى التمكين والتفويض السلطة لدى العاملين في المدارس الأردنية والأسترالية كان متوسطا وهذا يوحي بالحاجة إلى سياسة أكثر وضوحا فيما يتعلق بالتشريعات التوجيهات المدرسية لتتشيط عملية التمكين

$$
\text { وتقويض السلطة في المدارس. }
$$

- توجد فروق ذات دلالة إحصائية عند مستوى (150.05) في تقديرات المستجيبين لمستوى التمكين

$$
\text { الإداري وتفويض السلطة تعزى لمتغير المؤهل العلمي لصالح الدراسات العليا. }
$$


- لا توجد فروق ذات دلالة إحصائية عند مستوى (1>0.05) في تقديرات المستجيبين لمستوى التمكين الإداري وتفويض السلطة في المدارس الأردنية والأسترالية وفقا لنوع المدرسة ( المركزية أو اللامركزية ) وكانت هذه الفروق تعزى لصالح المعلمين في المدارس اللامركزية في كلا البلدين. وأوصت الدراسة بالتالي:

- إعادة النظر في برامج تعليم الطلبة المعلمين على مستوى الجامعات, تشمل مواضيع في التمكين وتقويض السلطة، وتزود الطلبة والمعلمين بالمعارف والمهارات والقيم اللازمة لممارسة هذه العملية, عندما يبدؤون العمل في المدارس.

- إجراء مزيد من الدراسات التجريبية حول القضايا المتصلة بتمكين المعلمين, وتفويضهح من أجل اقتراح

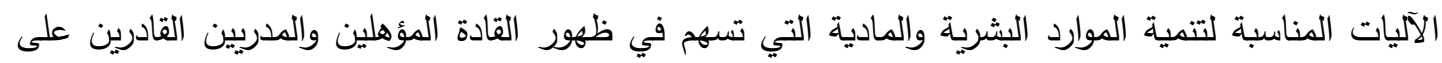
الوفاء بمتطلبات بيئة التعلم في مدارس القرن الحادي والعشرين. المنهجية والإجراءات

بناءً على طبيعة الدراسة والأهداف التي تسعى لتحقيقها فقد استخدم الباحث المنهج الوصفي التحليلي، والذي

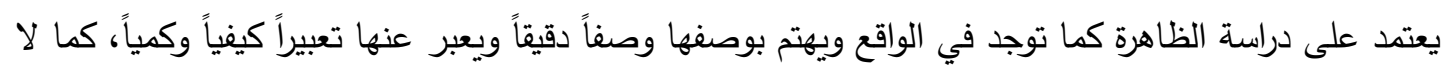
يكتفي هذا المنهج عند جمع المعلومات المتعلقة بالظاهرة من أجل استقصاء مظاهرها وعلاقاتها المختلفة، بل ولب

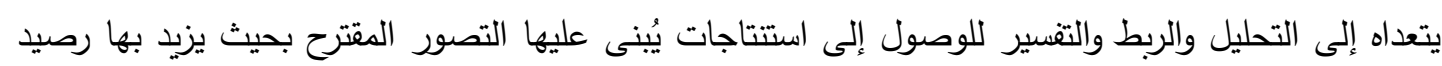

$$
\text { المعرفة عن الموضوع. }
$$

1- المصادر الثانوية: حيث اتجه الباحث إلى الكتب والمراجع العربية والأجنبية ذات العلاقة،

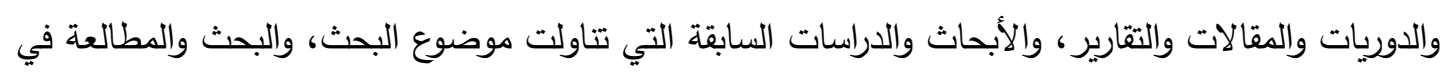
مواقع الإنترنت المختلفة. 2- المصادر الأولية: لمعالجة الجوانب التحليلية لموضوع البحث لجأ الباحث إلى جمع البيانات

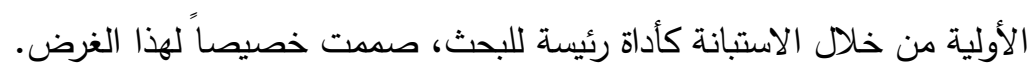

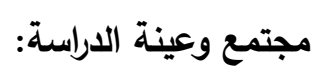

بناء على مشكلة الدراسة وأهدافها فإن مجتمع الدراسة يتكون من جميع العاملين في شبكة الأقصى للإعلام والإنتاج الفني، ممن يثغلون الوظائف الإشرافية من مدراء الأفرع ومدراء الدوائر ورؤساء الأقسام

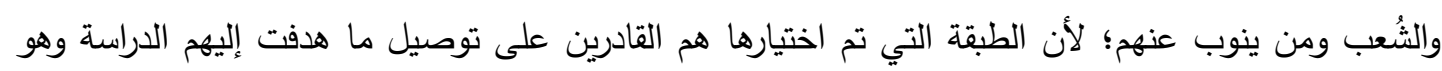

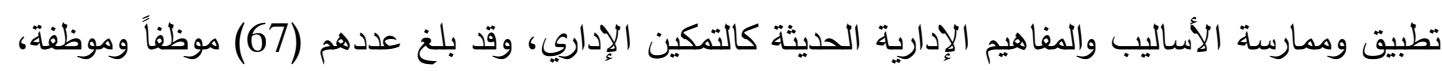
ونظراً لصغر حجم المجتمع فقد اعتمد الباحث أسلوب المسح الثامل لمجتمع الدراسة بناء على إلى الحصائيات

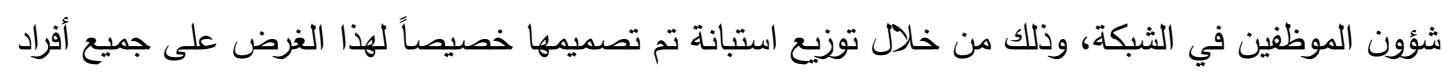

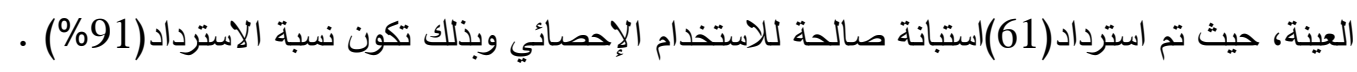

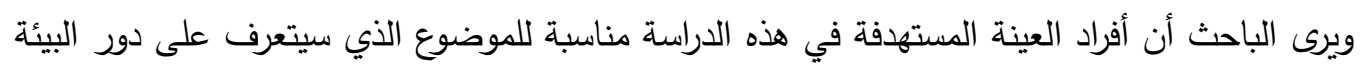

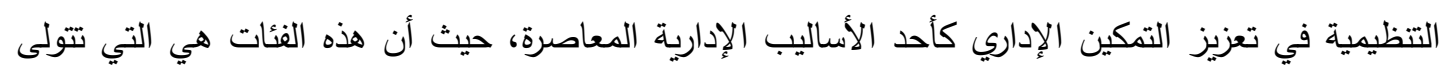

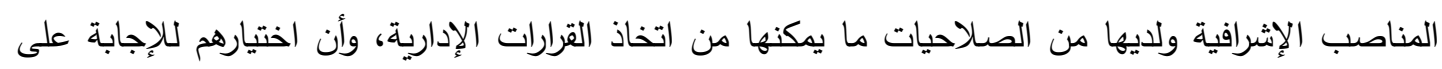

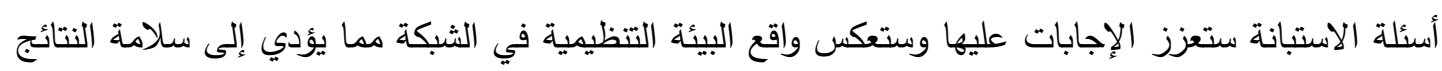
وتحقيق أهداف الدراسة. 
قام الباحث باستخدام الاستبانة كأداة لجمع البيانات وذلك لعدة اعتبارات منها: إمكانية الحصول على عدد كبير من الاستجابات في وقت قصير، إعطاء فرصة للمبحوث للإجابة بشكل أكثر دقة على أسئلة الاستبانة، قليلة التكلفة مقارنة بباقي الأساليب الإحصائية الأخرى. وتم إعداد استبانة حول " دور البيئة التتظيمية في تعزيز التمكين الإداري للعاملين في شبكة الأقصى الإسى

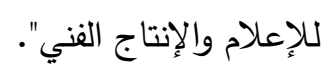

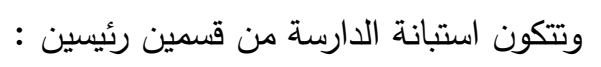

القسم الأول: وهو عبارة عن البيانات الثخصية عن المستجيب (الجنس، العمر، المؤهل العلمي،

$$
\text { المسمى الوظيفي، جهة العمل، سنوات الخدمة). }
$$

القسم الثاني دور البيئة التتظيمية في تعزيز التمكين الإداري للعاملين في شبكة الأقصى للإعلام والإنتاج

المعالجات الإحصائية المستخدمة في الدراسة:

Statistical Package for the تم تفريخ وتحليل الاستبانة من خلال برنامج التحليل الإحصائي

.Social Sciences (SPSS)

اختبار التوزيع الطبيعي Normality Distribution Test

تم استخدام اختبار كولمجوروف- سمرنوف Kolmogorov-Smirnov Test(K-S لاختبار ما إذا كانت البيانات تتبع التوزيع الطبيعي من عدمه، وأوضحت النتائج القيمة الاحتمالية (Sig) لجميع مجالات

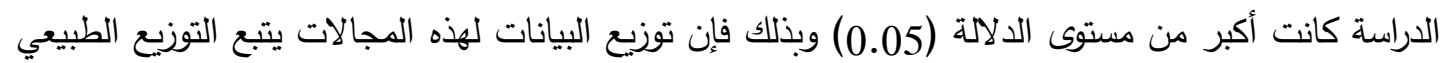

$$
\begin{aligned}
& \text { وحيث سيتم استخدام الاختبارات المعلمية للإجابة على فرضيات الدراسة. } \\
& \text { الوصف الإحصائي لعينة الاراسة وفق البيانات الثخصية : } \\
& \text { وفيما يلي عرض لخصائص عينة الدراسة وفق البيانات الثخصية. }
\end{aligned}
$$

\begin{tabular}{|c|c|c|}
\hline 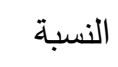 & 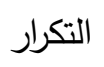 & الاستبانات \\
\hline 91.0 & 61 & استبانة مكتملة \\
\hline 9.0 & 6 & استبانة مفقودة (لم يتم الاجابة عليها) \\
\hline 100.0 & 67 & المجموع \\
\hline
\end{tabular}

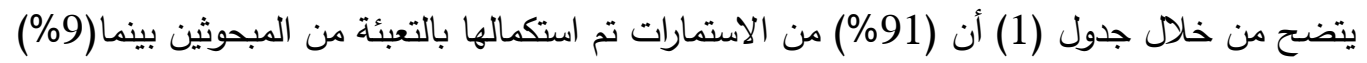

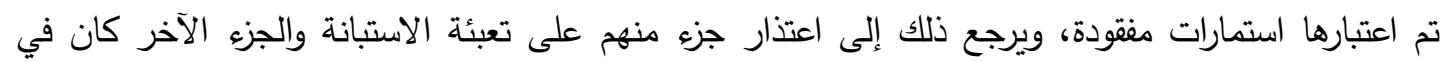
إجازة خاصة.

توزيع عينة الدراسة حسب متغير الجنس: 
يوضح الجدول رقم(2) توزيع أفراد مجتمع الدراسة حسب متغير الجنس، حيث نلاحظ بأن غالبية أفراد مجتمع الدراسة هم من الذكور وذلك بنسبة 96.7\% بواقع 59 موظف، بينما 3.3\% هن من الاناث بواقع(2)

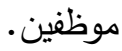

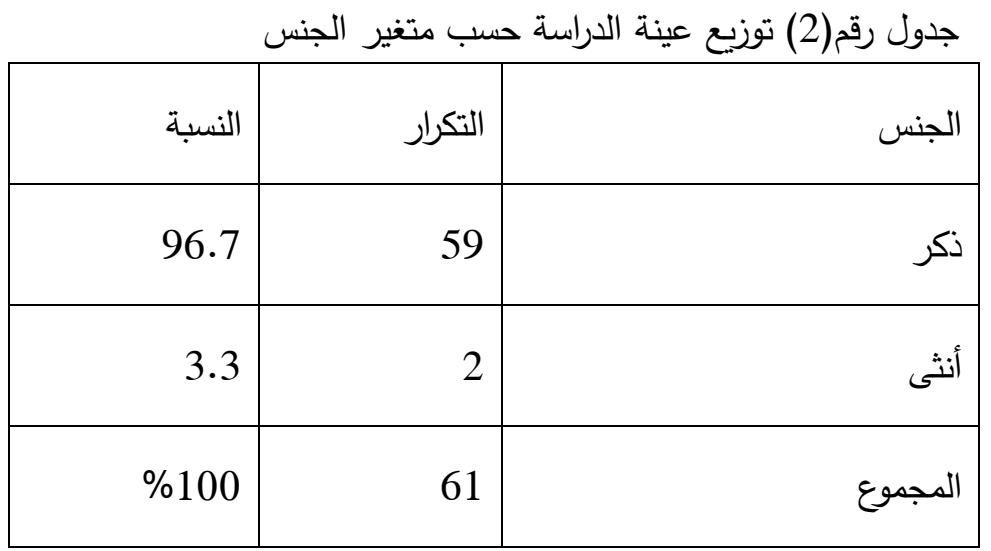

ويعزو الباحث تفوق نسبة الذكور على نسبة الإناث إلى طبيعة العوامل الثقافة السائدة في شبكة الأقصى التي تفضل العمل مع الذكور أكثر من العمل مع الإناث ويدل على ذلك بأن الموقع المخصص لعمل الإناث

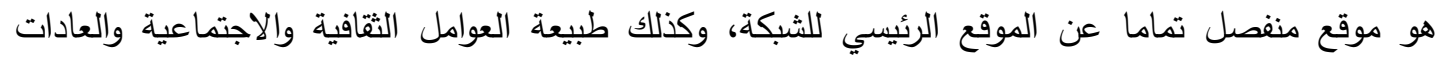
والتقاليد السائدة في المجتمع الفلسطيني، كما أن طبيعة العمل الإعلامي يحتاج إلى ساعات إضافية في العمل

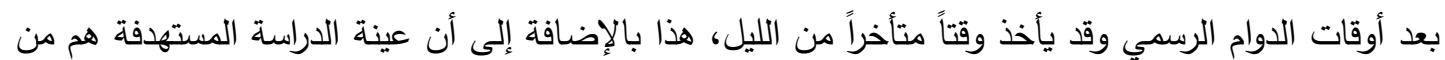

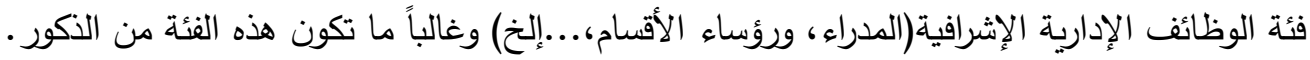

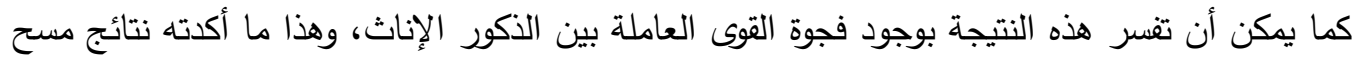
القوى العاملة في فلسطين للعام(2016) التي أفادت بوجود فجوة كبيرة في المشاركة في القوى العاملة بين الذكور والإناث حيث بلغت (71.6\%)للذكور مقابل(19.3\%)لإناث. (الجهاز المركزي للإحصاء الفلسطيني

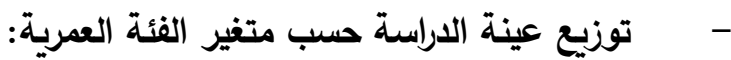

يوضح الجدول رقم(3) توزيع أفراد مجتمع الدراسة حسب متغير العمر، حيث يتضح من خلال النتائج

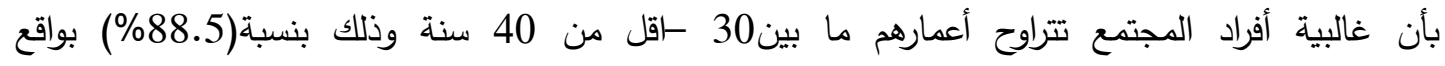
(54)موظف، بينما بلغت نسبة (8.2\%) في الفئة العمرية من 40 ـاقل من 50 سنة بواقع (5)موظفين، في بين

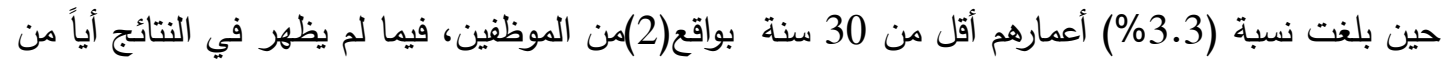
أفراد العينة من الموظفين تزيد أعمارهم عن (50) عاماً. جدول رقم(3) توزيع عينة الدراسة حسب متغير الفئة العمرية

\begin{tabular}{|c|c|c|}
\hline النسبة & 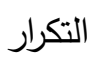 & الفئة العمرية \\
\hline 3.3 & 2 & أقل من 30 سنة \\
\hline 88.5 & 54 & من 30-أقل من 40 سنة \\
\hline 8.2 & 5 & من 40-أقل من 50 سنة \\
\hline
\end{tabular}




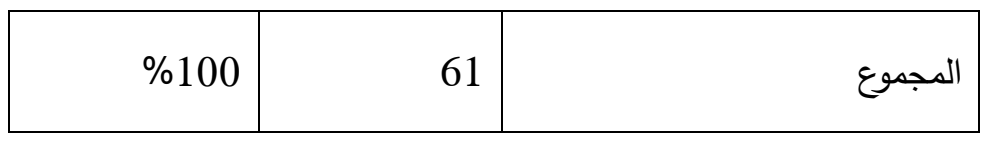

ويفسر الباحث أن الفئة العمرية لعينة الدراسة (من 30 سنة إلى أقل من 40 سنة) كانت بنسبة(88.5\%) وهي النسبة الأكبر من عينة الدراسة، أي أن الغالبية من موظفي الثبكة هم من العناصر

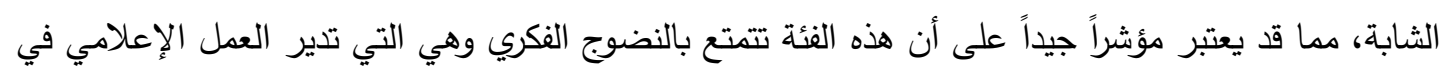

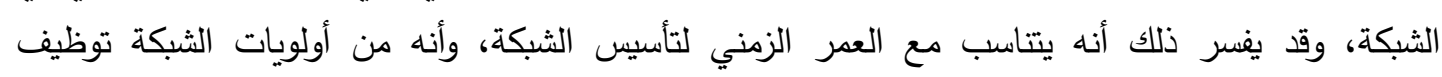

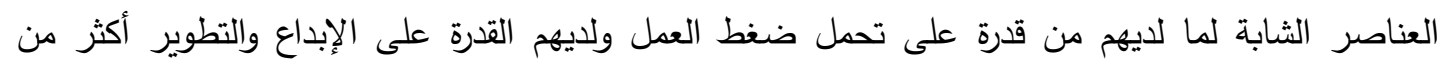
الفئات العمرية الأخرى، وأيضاً يعود ذلك إلى أن حركة وتتقل الثباب تكون أسهل من غيرهم وخاصة في أولى أوقات الطوارئ والأحداث العاجلة والفعاليات الأخرى.

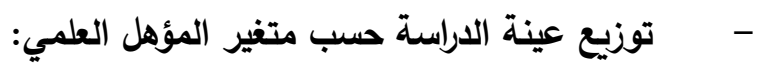

يوضح الجدول رقم(4) توزيع أفراد مجتمع الدراسة حسب متغير المؤهل العلمي، حيث يتضح من من خلادل النتائج بأن(63.9\%) مؤهلهم العلمي بكالوريوس بواقع(39)موظف، ثم يليهم الحاصلين على الدرجة العلمية

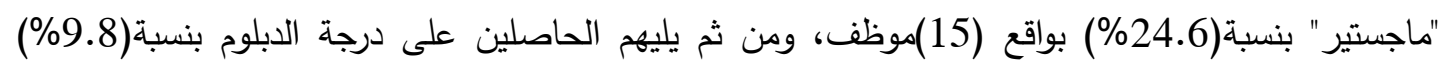

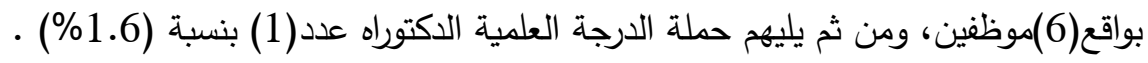

\begin{tabular}{|c|c|c|}
\hline النسبة & التكرار & المؤهل العلمي \\
\hline 1.6 & 1 & دكتوراه \\
\hline 24.6 & 15 & ماجستير \\
\hline 63.9 & 39 & بكالوريوس \\
\hline 9.8 & 6 & دبلوم \\
\hline$\% 100$ & 61 & المجموع \\
\hline
\end{tabular}

ويعزو الباحث ارتفاع نسبة الموظفين حملة المؤهل العلمي البكالوريوس بنسبة(63.9\%) إلى أنهم ممن يشغلون الوظائف الإشرافية والتي تحتاج إلى مؤهلات علمية كحد أدنى على الثهادة الجامعية الأولى، والتي

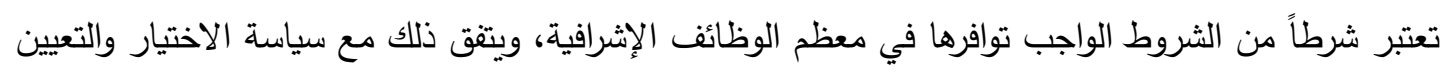

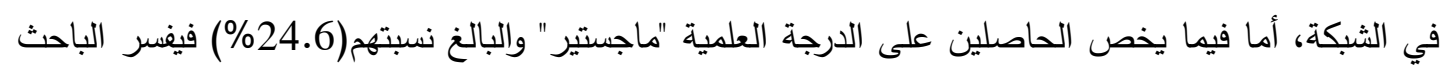
ذلك بأنه يعود إلى ازدياد نسبة المتجهين نحو تطوير أنفهم أكاديمياً للحصول على مؤهلات علمية عليا، وهذا بطبيعة الحال يعطي اطمئنان للباحث بأن عينة الدراسة لديهم القدرة على فهم أسئلة الاستبانة والإجابة عليها،

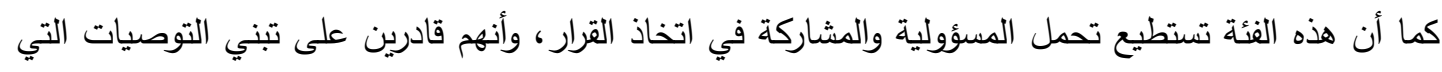
ستتتج عن هذه الدراسة والعمل بها للارتقاء بالكادر البشري للنهوض بمؤسسات شبكة الأقصى وتحقيق أهدافها. 


\section{- - مزيع عينة الاراسة حسب متغير المسمى الوظيفي:}

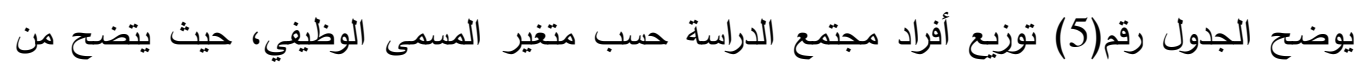

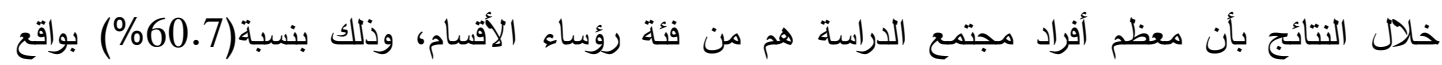

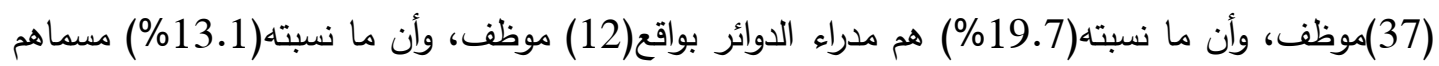

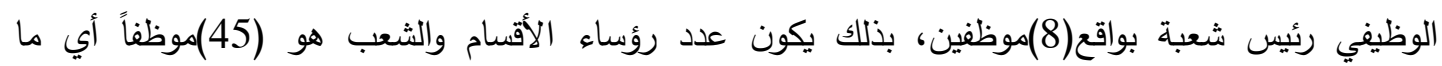

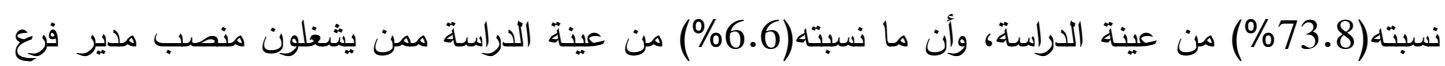
وبواقع(4) موظفين. وهذا يؤشر إلى أن الاستبانة تم توزيعها على الجهات ذات العلاقة بالقرارات الإدارية

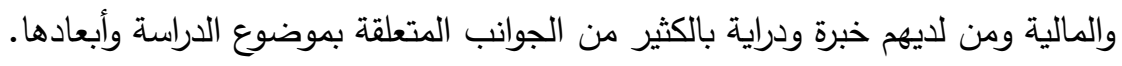

\begin{tabular}{|c|c|c|}
\hline النسبة & التكرار & المسىى الوظيفي \\
\hline 6.6 & 4 & مدير فرع \\
\hline 19.7 & 12 & مدير دائرة \\
\hline 60.7 & 37 & رئيس قسم \\
\hline 13.1 & 8 & رئيس شعبة \\
\hline$\% 100$ & 61 & المجموع \\
\hline
\end{tabular}

ويتبين من الجدول السابق أن نسبة المسمى الوظيفي للمناصب الإدارية رئيس قسم وشعبة ما نسبته(73.8\%) من عينة الدراسة تفوق باقي الفئات الأخرى والبالغ عددهم(45)موظفاً وهم النسبة الأكبر مقارنة بمدراء الدوائر ، ويرى الباحث أنها نسبة منطقية تعكس صحة وسلامة الهيكل التتظيمي المطبق في شبكة الأقصى، حيث يقل عدد شاغلي الوظائف الإشرافية كلما اتجهنا لأعلى في الهرم الوظيفي، كما أن هذه الفئة النئة

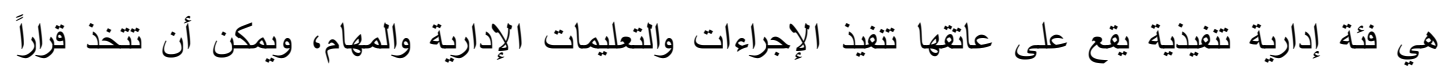
بتطبيق التمكين الإداري في ظل بيئة تتظيمية تتمتع بهيكل تتظيمي موزع بثكل إداري سليم.

\section{- - توزيع عينة الدراسة حسب متفير جهة العمل:}

يوضح الجدول رقم(6) توزيع أفراد مجتمع الدراسة حسب متغير جهة العمل، حيث يتضح من خلال

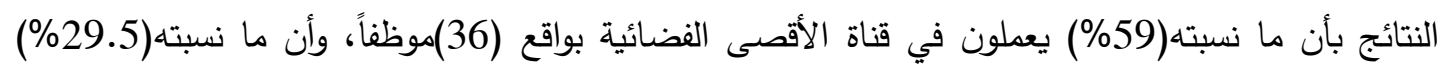
يعملون إذاعة صوت الأقصى بواقع(18)موظفاً، وأن ما نسبته (6.6\%) يعملون في وكان وكالة شهاب لكلأنباء بواقع(4)موظفين، وأن ما نسبته(4.9\%) بواقع(3)موظفين يعملون في مرئية الأقصى. وهذا يؤشر إلى أن قناة الأقصى الفضائية هي الأكثر عدداً في الموظفين، وكذلك من ناحية عدد متخذي القرارات مقارنة بالمؤسسات الأخرى التابعة لشبكة الأقصى. 
جدول رقم(6) توزيع عينة الدراسة حسب متغير جهة العمل

\begin{tabular}{|c|c|c|}
\hline النسبة & 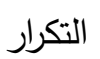 & جهة العمل \\
\hline 59.0 & 36 & قناة الأقصى الفضائية \\
\hline 29.5 & 18 & إذاعة صوت الأقصى \\
\hline 4.9 & 3 & مرئية الأقصى \\
\hline 6.6 & 4 & وكالة شهاب للأنباء \\
\hline
\end{tabular}

ويعزو الباحث ارتفاع نسبة العاملين في قناة الأقصى الفضائية بنسبة(59\%) لأنها هي الأكثر عددا من

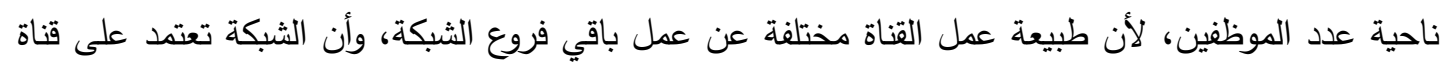
الأقصى الفضائية عن غيرها من الأفرع بثكل أكبر لأنها تبث عبر الفضاء لمعظم دول العالم، كما أن الهيكل

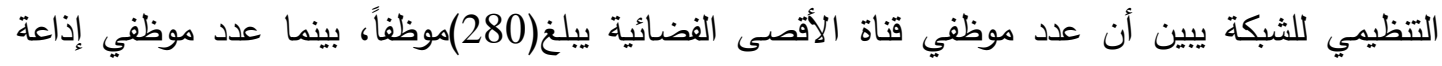

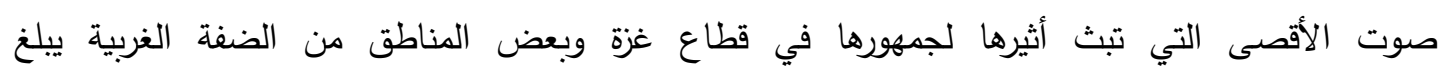
عددهم(90)موظفاً، وعدد موظفي مرئية الأقصى التي تهدف إلى إرسال صورتها للأسرى الفلسطينيين داخل السجون الصهيونية في الأراضي الفلسطينية المحتلة ويبلغ عددهم(19)موظفاً، بينما يبلغ عدد موظفي وكالة شهاب للأنباء (18)موظفاً. (النشرة التعريفية لشبكة الأقصى الإعلامية الصنية)

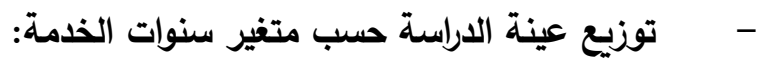

يوضح الجدول رقم(7) توزيع أفراد مجتمع الدراسة حسب متغير سنوات الخدمة، حيث يتضح من من خلات

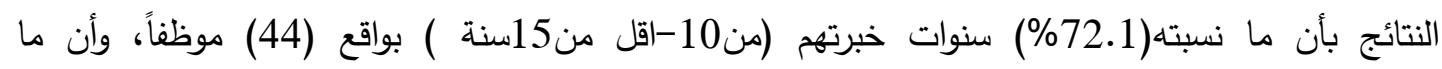

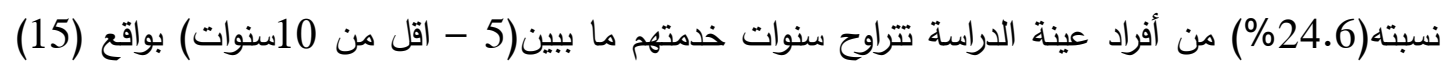
موظفاً، وأن ما نسبته(3.3\%) من أفراد عينة الدراسة خدمتهم أقل من(5) سنوات بواقع(2) موظف، فئوات فيما لم تظهر النتائج أياً من أفراد العينة أن سنوات خدمتهم في شبكة الأقصى تزيد عن 15 عاماً. جدول رقم(7) توزيع عينة الدراسة حسب متغير سنوات الخدمة

\begin{tabular}{|c|c|c|}
\hline النسبة & التكرار & سنوات الخدمة \\
\hline 3.3 & 2 & أقل من 5 سنوات \\
\hline 24.6 & 15 & من 5-أقل من 10 سنوات \\
\hline 72.1 & 44 & من 10-أقل من 15 سنة \\
\hline _ & - & 15 سنة فأكثر \\
\hline
\end{tabular}




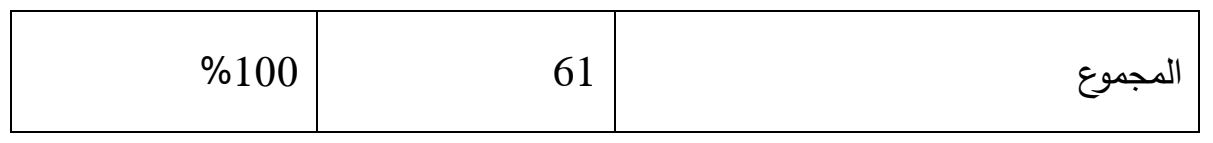

وقد يعزو الباحث تفوق نسبة سنوات الخدمة (من 10 - أقل من 15 سنة) والتي تمثل نسبة(72.1\%)

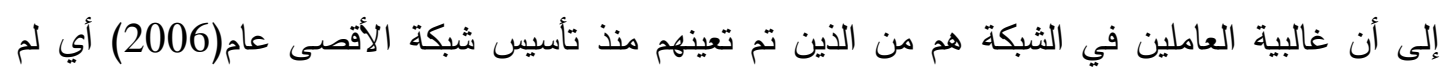

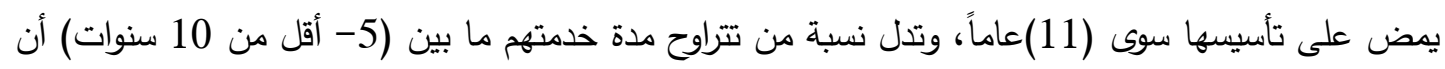

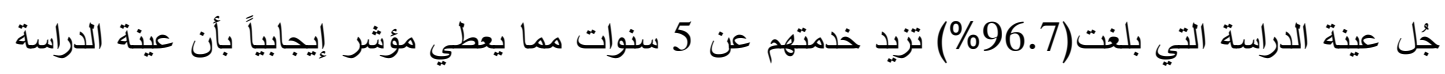

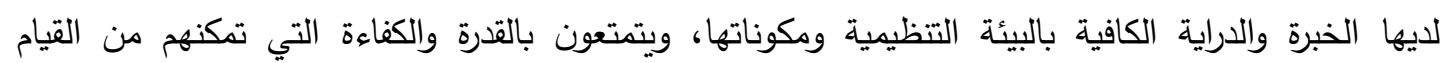
بأعمالهم، مما يطمئن الباحث بأن ارتفاع عدد سنوات خدمتهم يساعد على فهم أسئلة الدراسة والإجابة عليها

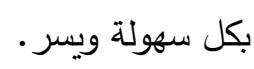

اختبار الفرضيات : (1)

الفرضية الرئيسية الأولى: توجد علاقة ذات دلالة إحصائية عند مستوى (1<0.05) بين دور البيئة

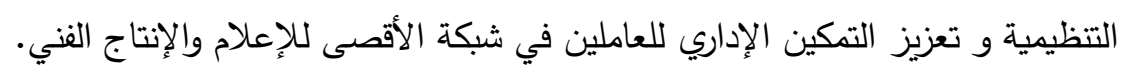

جدول (8) معامل الارتباط بين دور البيئة التتظيمية و تعزيز التمكين الإداري للعاملين في شبكة الأقصى

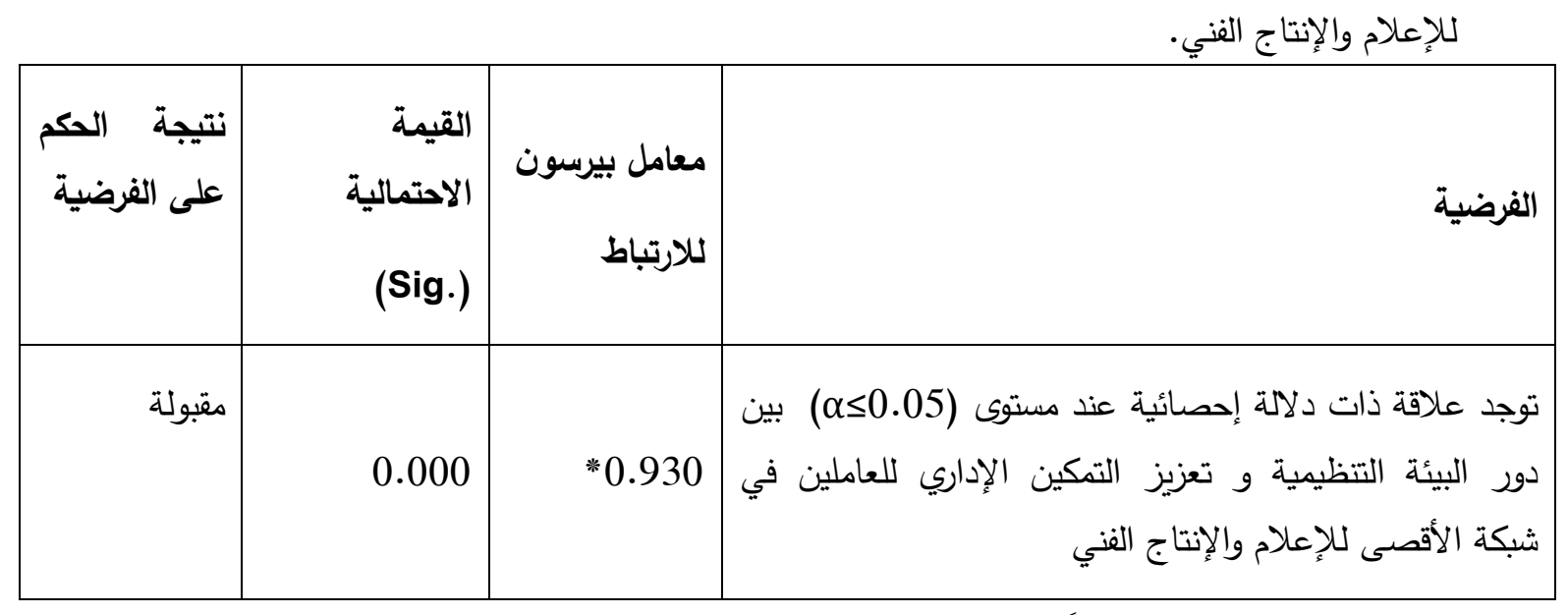

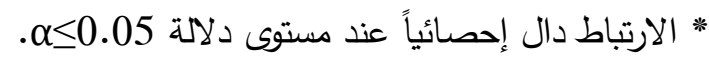

يبين جدول رقم (8) أن معامل الارتباط يساوي(0.930)، وأن القيمة الاحتمالية (.Sig) تساوي (0.00)

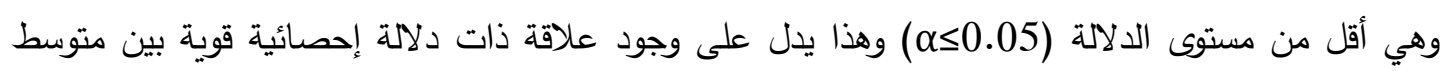
تقديرات المبحوثين حول دور البيئة التتظيمية و تعزيز التمكين الإداري للعاملين في شبكة الأقصى للإعلام

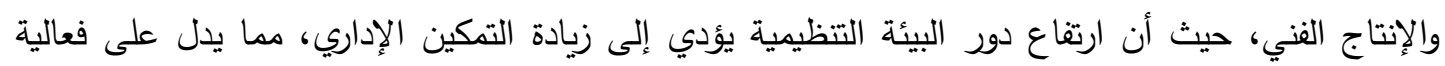

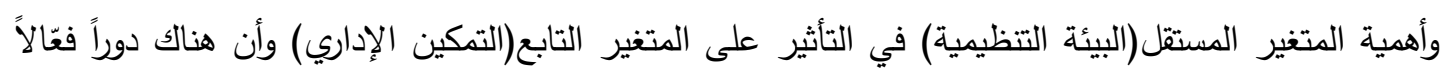

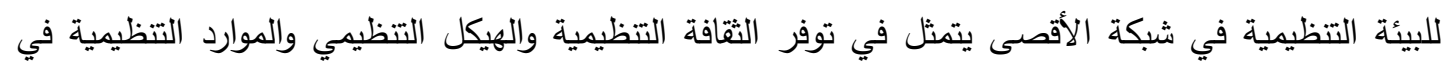
الثبكة، وهذا ما يثبت صحة الفرضية الأولى للدارسة.

ويعزو الباحث وجود علاقة ارتباطية موجبة بين البيئة التظيمية وأبعاد التمكين الإداري أي أن البيئة

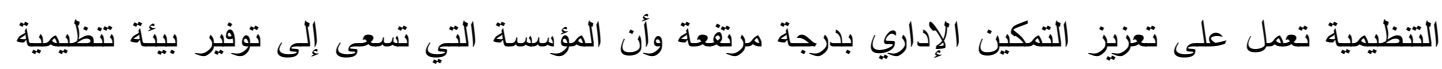

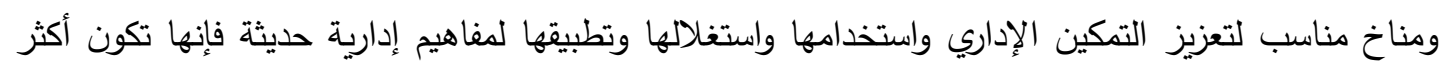
قدرة وفعالية على تحقيق أهدافها. 
واتتقت نتائج هذه الدراسة بعض الدراسات الأخرى مثل دراسة(أبو شعيرة، 2016) والتي أظهرت

وجود علاقة بين بيئة العمل للموارد البشرية وبين الأمن الوظيفي، ودراسة (نصار، 2016) التي بينت أنه يوجد

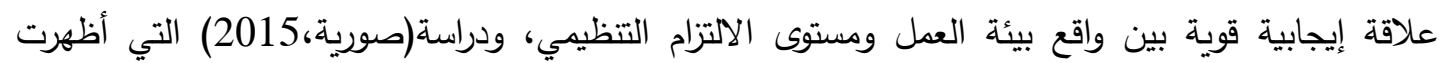
نتائجها وجود علاقة ارتباط معنوية بين توفير البيئة التظظيمية وفعالية تطبيق إدارة المعرفة ودراسة(الثمري، 2013) والتي بينت وجود علاقة قوية بين بيئة العمل الداخلية ومستوى الالتزام التتظيمي، ودراسة (سمارة ،2017) التي أظهرت وجود علاقة ذات دلالة إحصائية بين إدارة التتوع في الموارد البشرية والثقافة التنظيمية. واختلفت مع دراسة(2016) التي أظهرت وجود علاقة ارتباطية سالبة بين المناخ التظيمي والصمت التتظيمي، وعلاقة سالبة بين أبعاد المناخ التظظيمي والصمت الوظيفي. و يتفرع منها الفرضيات الفرعية الآتية :

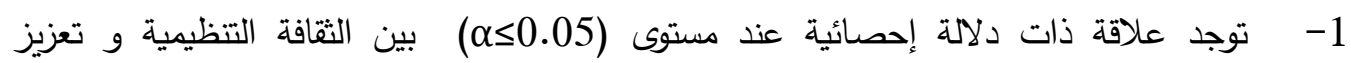
التمكين الإداري للعاملين في شبكة الأقصى للإعلام والإنتاج الفني. جدول (9) معامل الارتباط بين الثقافة التظيمية و تعزيز التمكين الإداري للعاملين في شبكة الأقصى للإعلام \begin{tabular}{|r|r|r|l|}
\hline والإنتاج الفني \\
\hline \\
\hline
\end{tabular} يبين جدول رقم (9) أن معامل الارتباط يساوي (0.785)، وأن القيمة الاحتمالية (Sig) تساوي

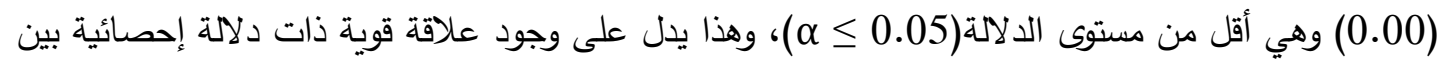
متوسط تقديرات المبحوثين حول (الثقافة التنظيمية) و تعزيز التمكين الإداري للعاملين، بمعنى أنه كلما زادت وهن

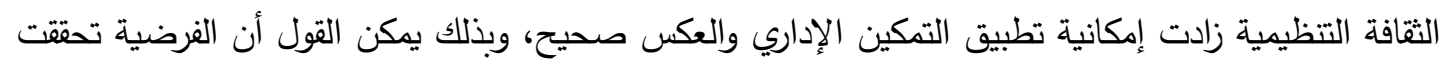
وبالتالي قبول الفرضية. ويعزو الباحث ذلك إلى أن إدارة الثبكة تسعى إلى خلق ثقافي والى تنظيمية مشجعة للإبداع

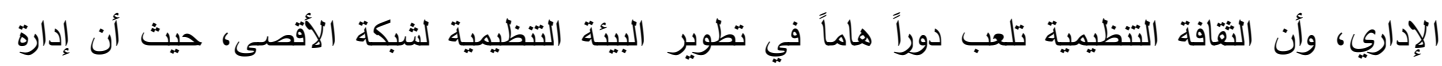
الثبكة وسياساتها الداخلية لها دور كبير في نجاح وإفثال دور الثقافة التنظيمية وهي أي (الثقافة التتظيمية) التي تحدد سلوكهم تجاه تبني مفاهيم إدارية حديثة كالتمكين الإداري، كما أنها تجعل العاملين في الشبكة تتبنى

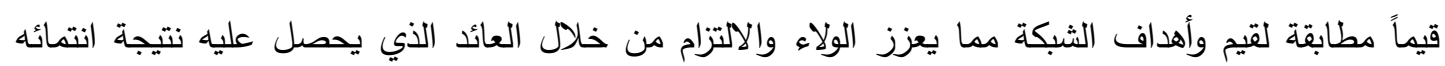
والتحاقه في العمل داخل مؤسسات شبكة الأقصى. واتفقت نتائج هذه الدراسة مع بعض الدراسات الأخرى كدراسة (السحباني، 2016) التي أظهرت وجود علاقة قوية بين الثقافة التظيمية والسلوك الإبداعي ودراسة(صورية، 2015) والتي بينت وجود علاقة قوية بين 
الثقافة التنظيمية وتطبيق عمليات إدارة المعرفة، ودراسة(Akhavan,2014) التي أظهرت أن الثقافة التظظيمية السائدة لها تأثير واضح على أبعاد عمليات المعرفة الإدارية، ودراسة(جلولي، 2013) التي أظهرت نتائجها

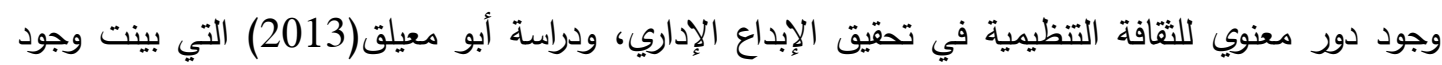

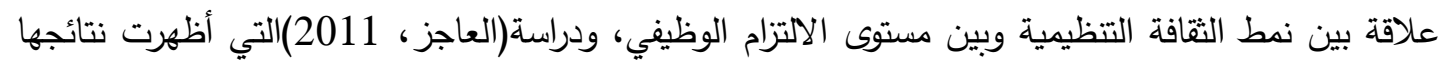

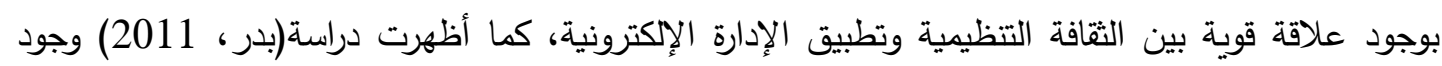

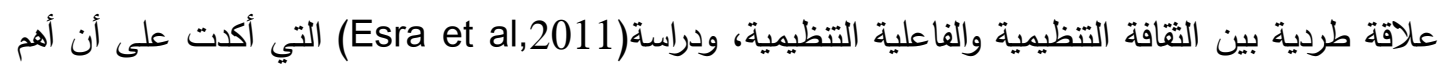
العوامل التي تؤثر على الكفاءة والإبداع الإداري لدى المديرين والقيادة الإدارية هي الثقافة التتظيمية.

وبذلك يكون قد اتفتت الدراسات الدذكورة أعلاه مع الدراسة الحالية في وجود علاقة بين الثقافة التتظيمية

ومتغيرات أخرى مثل(السلوك الإبداعي، إدارة المعرفة، الالتزام الوظيفي، الإدارة الإكترونية، الفاعلية التتظيمية)

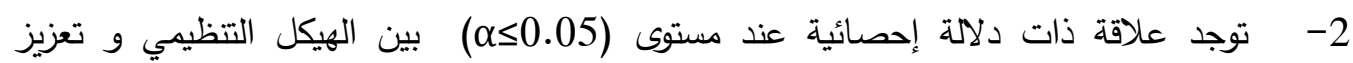
التمكين الإداري للعاملين في شبكة الأقصى للإعلام والإنتاج الفني. جدول (10) معامل الارتباط بين الهيكل التتظيمي و تعزيز التمكين الإداري للعاملين في شبكة الأقصى للإعلام

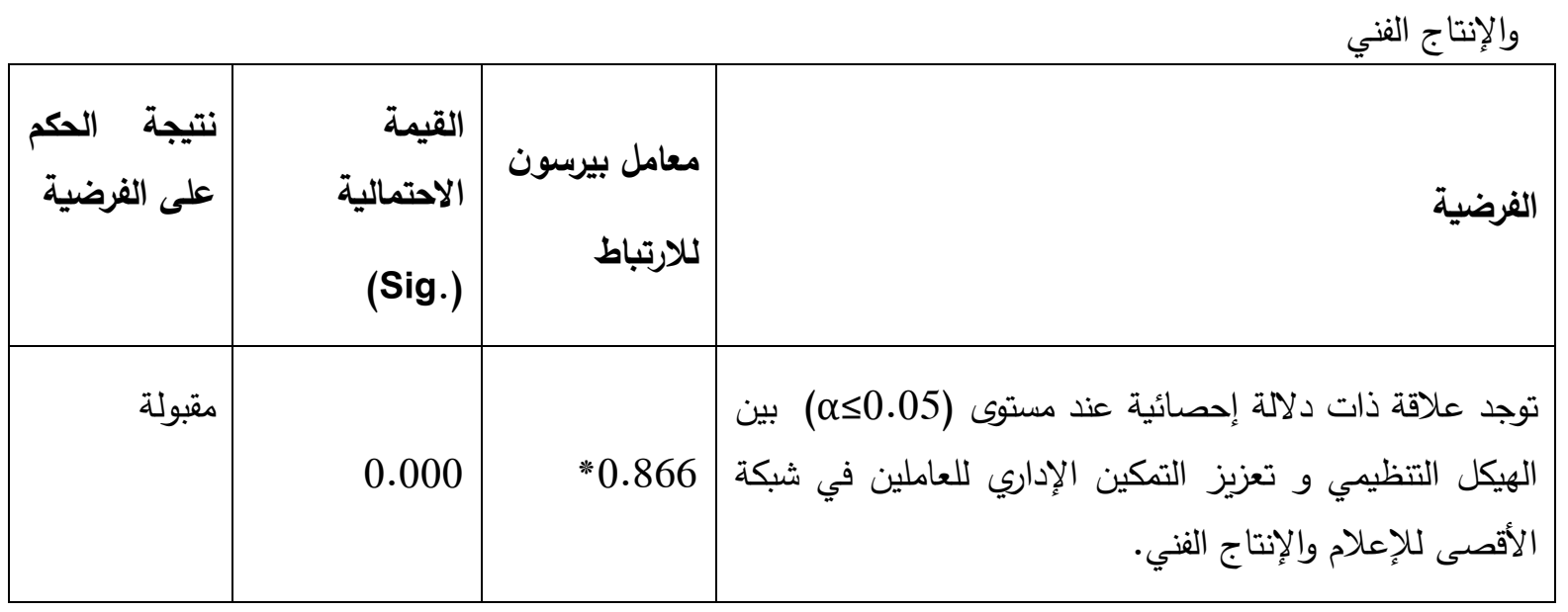

* الارتباط دال إحصائياً عند مستوى دلالة (10005).

يبين جدول رقم (10) أن معامل الارتباط يساوي (0.866)، وأن القيمة الاحتمالية (.Sig) تساوي

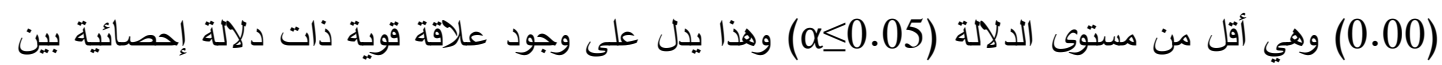
متوسط تقديرات المبحوثين حول الهيكل التتظيمي وتعزيز التمكين الإداري للعاملين في شبكة الأقصى للإعلام

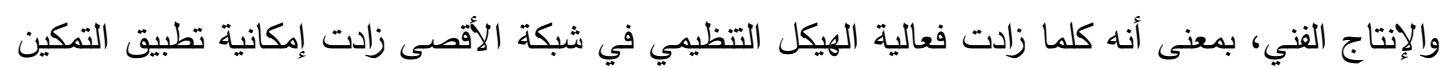

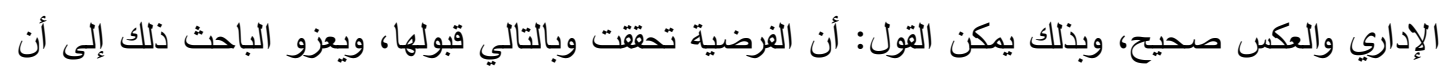
الهيكل التظيمي يعكس دوراً مهما في تعزيز التمكين الإداري و آلية اتخاذ القرارات .

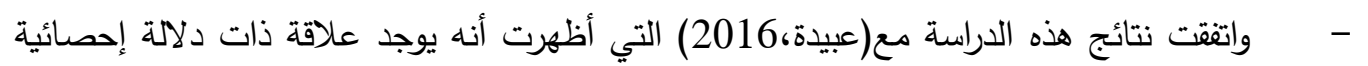
بين الهيكل التنظيمي والسلوك الإبداعي، ودراسة(الهابيل، 2016) التي أظهرت وجود علاقة ذات دلاتلة

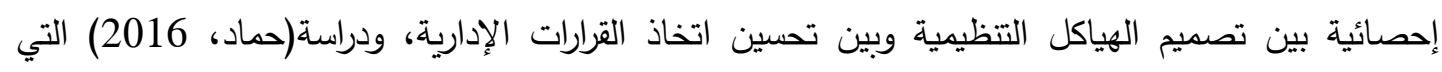
أظهرت وجود علاقة ذات دلالة إحصائية بين محددات تصميم الهياكل التنظيمية واتخاذ القرارات الإدارية في

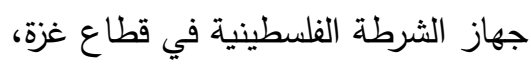
ودراسة(العووادة،2014) حيث أظهرت وجود علاقة ذات دلالة إحصائية بين الهيكل التظظيمي،

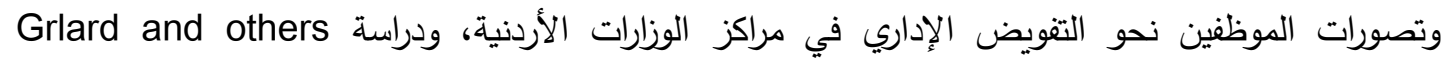


(2013) التي بينت أنه يوجد علاقة بين الهيكل التنظيمي وإدارة المعرفة، ودراسة(المشوط، دأناف) التي أظهرت وجود تأثير ذي دلالة معنوية للهيكل التتظيمي على الإبداع الإداري(السلوك الإبداعي، والقدرات الإبداعية).

وبذلك يكون قد اتفت الدراسة الحالية مع الدراسات المذكورة أعلاه في وجود علاقة بين الثقافة التظيمية

ومتغيرات أخرى مثل (السلوك الإبداعي، القدرات الإبداعية، اتخاذ القرارات، إدارة المعرفة، الثعور بالتمكين).

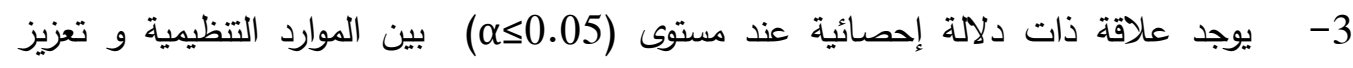

التمكين الإداري للعاملين في شبكة الأقصى للإعلام والإنتاج الفني.

جدول (11) معامل الارتباط بين الموارد البشرية و تعزيز التمكين الإداري للعاملين في شبكة الأقصى للإعلام

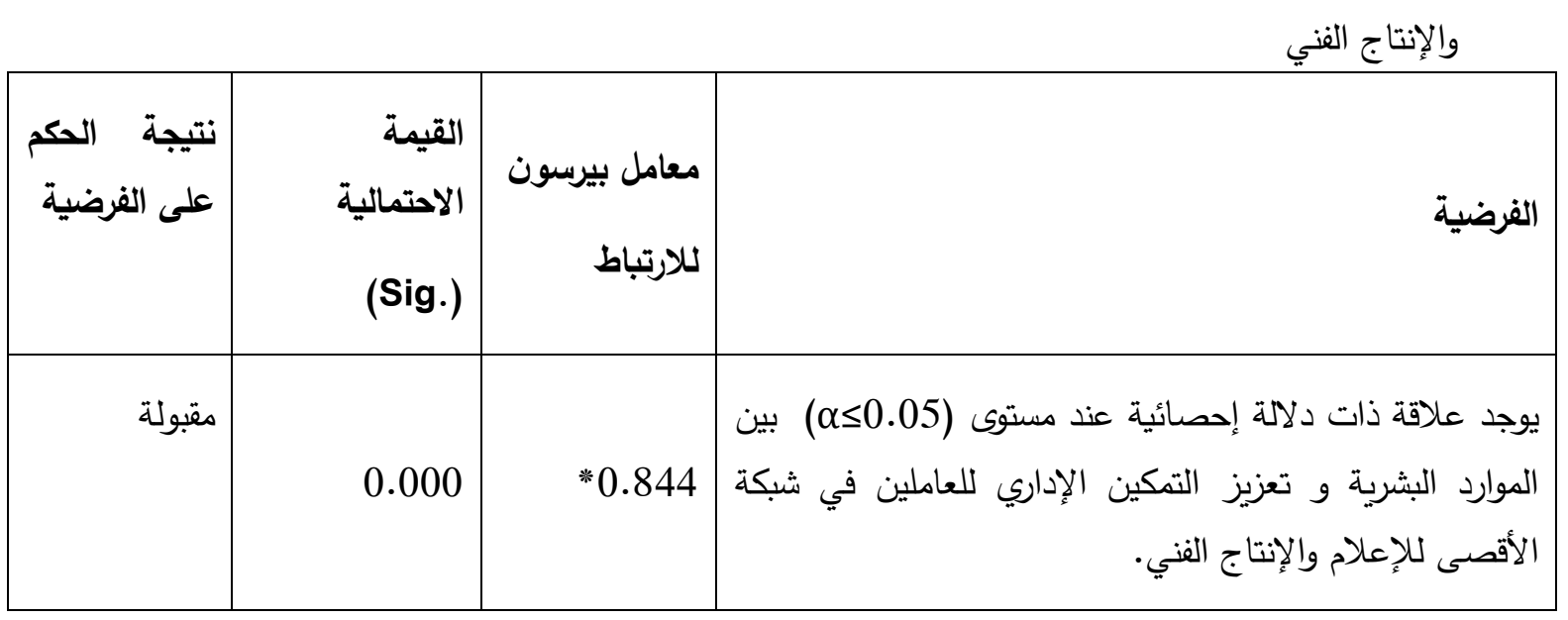

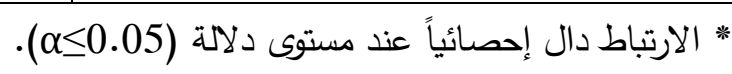

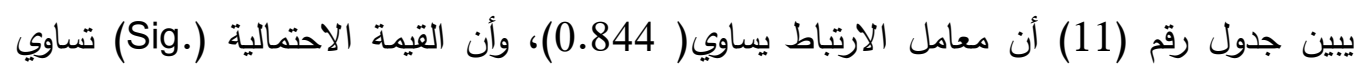
(0.00) وهي أقل من مستوى الدلالة (1<0.05) وهذا يدل على وجود علاقة قوية ذات دلالة إحصائية بين متوسط تقديرات المبحوثين حول الموارد التظظيمية وتعزيز التمكين الإداري للعاملين في شبكة الأقصى للإعلام

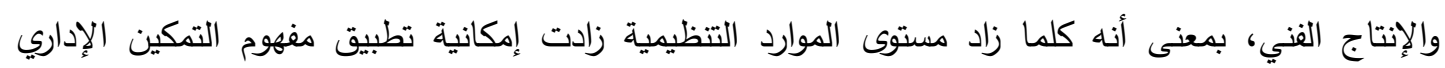

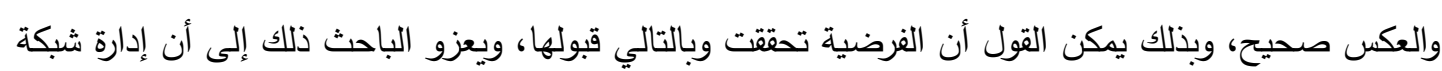
الأقصى تسعى إلى توفير موارد تتظيمية مناسبة لما لها من أهمية كبيرة في تعزيز التمكين الإداري.

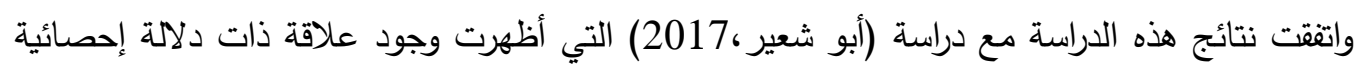

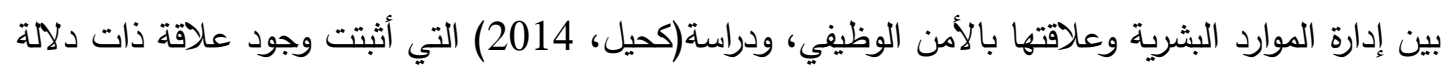
إحصائية بين أبعاد إدارة الموارد البشرية وكفاءة أداء العاملين في الجامعات الفلسطينية.

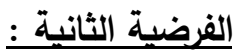

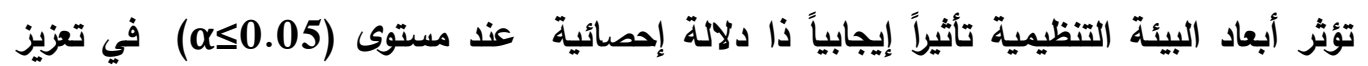
التمكين الإداري للعاملين في شبكة الأقصى للإعلام والإنتاج الفني.

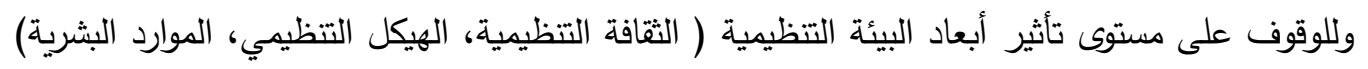
مُجتمعة على تعزيز التمكين الإداري للعاملين في شبكة الأقصى للإعلام والإنتاج الفني، استخدم الباحث

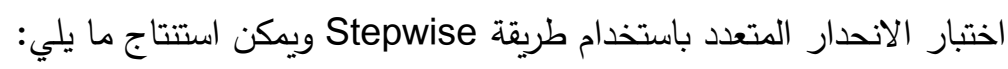


أ- يبين نموذج الانحدار النهائي باستخدام طريقة Stepwise أن تعزيز التمكين الإداري وهو يمثل المتغير التابع يتأثر بصورة جوهرية وذات دلالة إحصائية بكل من المتغيرات (الهيكل التتظيمي، الموارد البشرية، الثقافة التتظيمية). ب- - أظهرت نتائج التحليل أن معامل الارتباط بلغ (0.935)، بينما بلغ معامل التحديد (0.874) و

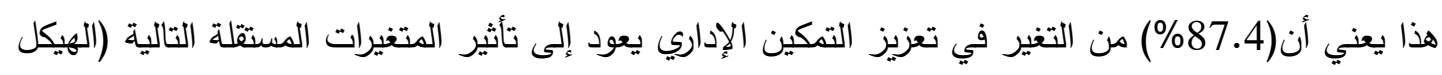

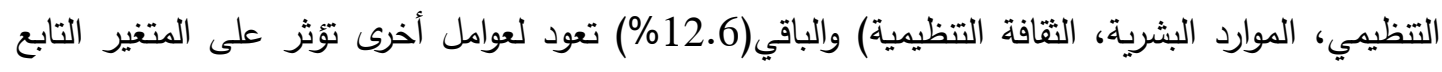
في تعزيز التمكين الإداري.

جدول (12) نتائج اختبار تحليل الانحدار المتعدد لتأثير ابعاد البيئة التظيمية في تعزيز التمكين الإداري

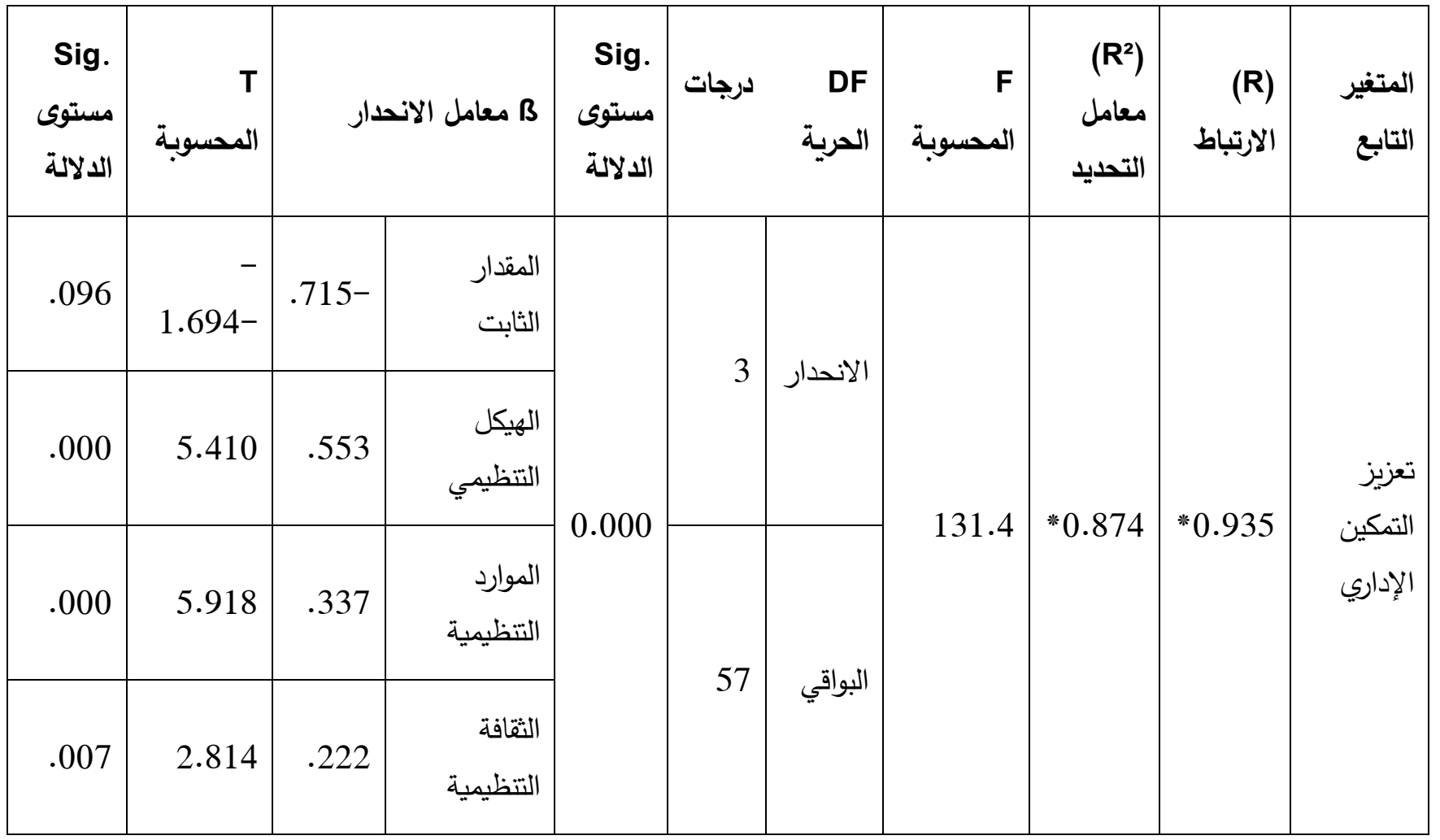


معادلة التأثير :

\begin{tabular}{|c|c|c|c|c|c|c|c|c|}
\hline 0.222 & & 0.337 & & 0.553 & & & & \\
\hline الثقافة & + & الموارد & + & الهيكل & + & 0.715 & $=$ & \\
\hline التنظيمية & & التنظيمية & & 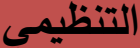 & & & & ك الإداريي \\
\hline
\end{tabular}

في حالة تتبيت قيمة (الموارد التنظيمية، التقافة التظيمية) وعند زيادة (الهيكل التنظيمي) بمقدار وحدة واحدة يؤدي إلى زيادة المتغير التابع (تعزيز التمكين الإداري) بمقدار (0.553).

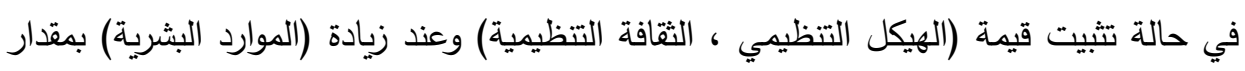
وحدة واحدة يؤدي إلى زيادة المتغير التابع تعزيز التمكين الإداري بمقدار (0.337).

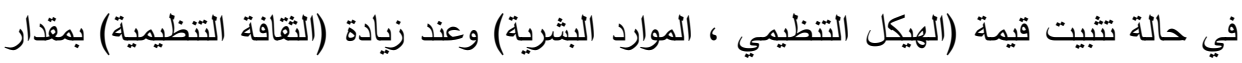
وحدة واحدة يؤدي إلى زيادة المتغير التابع تعزيز التمكين الإداري بمقدار (0.222).

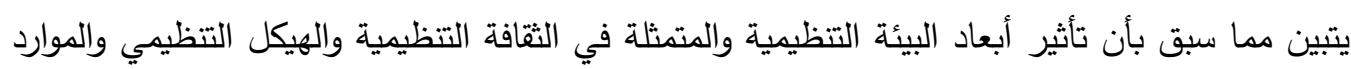
التنظيمية يؤثر تأثيراً جوهرياً على التصكين الإداري في شبكة الأقصى، وبناءً عليه نقبل بالفرض الرئيس التئ الثاني.

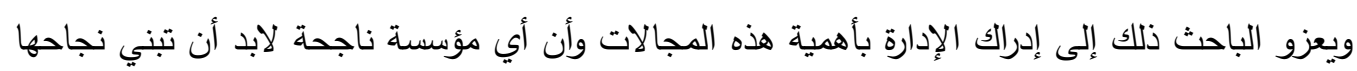

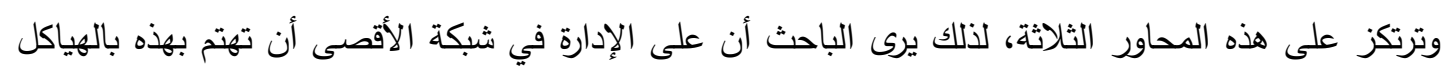

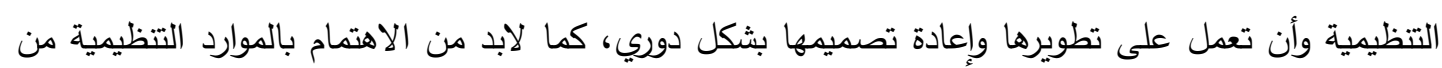

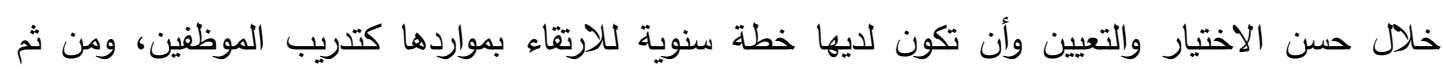

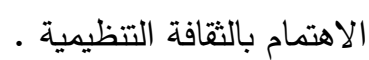

\section{نتائج الارراسة}

بناء على الدراسة الميدانية التي قام بها الباحث حول دور البيئة التظظيمية في تعزيز التمكين الإداري للعاملين في شبكة الأقصى الإعلامية، فقد توصلت الدراسة إلى مجموعة من النتائج من خلال البيانات التي تم جمعها من الاستبانة، وتم عرض وتقسير النتائج ومقارنتها بنتائج الدراسات السابقة ذات العلاقة، وسيتم في هذا الفصل استخلاص أهم النتائج التي توصل إليها الباحث، وكذلك أهم التوصيات المقترحة، وهي كالآتي: • نتائج التحليل الوصفي وخصائص العينة: 1- أظهرت نتائج الدارسة أن المتوسط الحسابي النسبي لمجالات البيئة التظظيمية مجتمعة(62.61\%) وهذا يعني أن هناك موافقة بدرجة متوسطة من قبل أفراد العينة. 2- أشارت النتائج إلى أن مجالات البيئة التنظيمية جاءت بأوزان نسبية حسب الترتيب التالي: - - التقافة التظيمية: المرتبة الأولى بمتوسط حسابي نسبي(66.59\%). 
- - الهيكل التظظيمي: المرتبة الثانية بمتوسط حسابي نسبي(64.31\%).

- - الموارد التظيمية: المرتبة الثالثة بمتوسط حسابي نسبي (56.94\%).

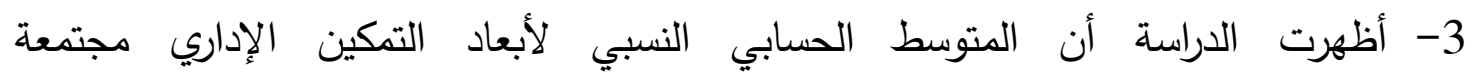
بلغت(62.34\%) وهذا يعني أن هناك موافقة بدرجة متوسطة على أبعاد التمكين الإداري، وجاءت الإدئ الأبعاد حسب الترتيب التالي:

- تقويض السلطة : المرتبة الأولى بمتوسط حسابي نسبي(66.92\%).

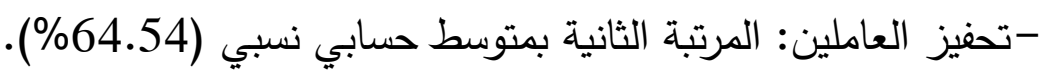

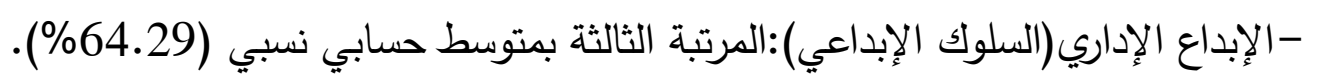
-فرق العمل(العمل الجماعي): المرتبة الرابعة بمتوسط حسابي نسبي (63.05\%).

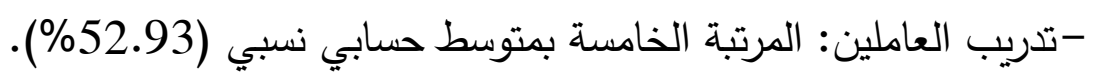
4- خلصت الدراسة إلى أن ما نسبته(96.7\%) من أفراد عينة الدراسة هم من الذكور ، وأن أكثر (52. من (88.5\%) من أفراد العينة تقل أعمارهم عن (40) عاماً، كما أن ما نسبته(

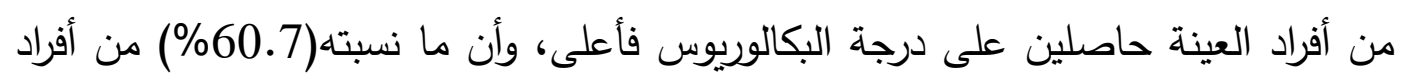

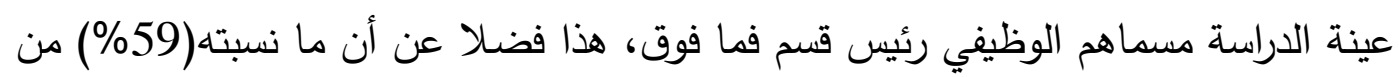

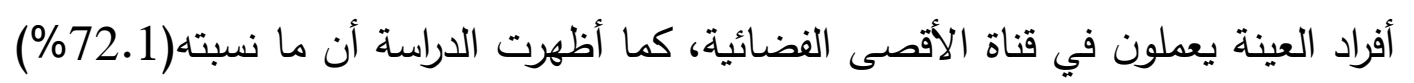

$$
\begin{aligned}
& \text { تزيد مدة خدمتهم عن } 10 \text { سنوات. }
\end{aligned}
$$

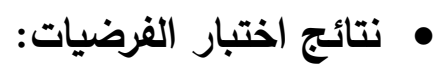

$$
\begin{aligned}
& \text { أ. النتائج الخاصة بالعلاقة بين المتغيرات: }
\end{aligned}
$$

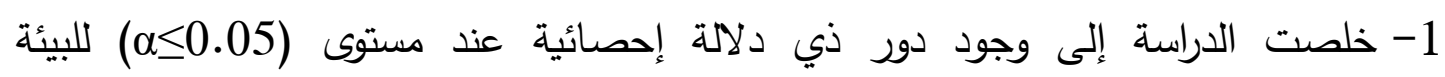

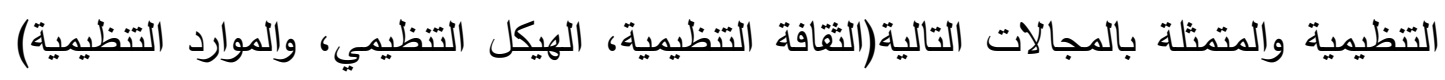

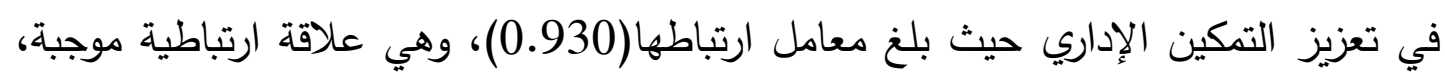

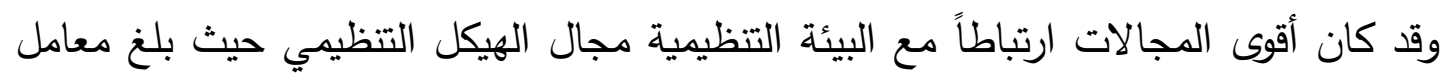

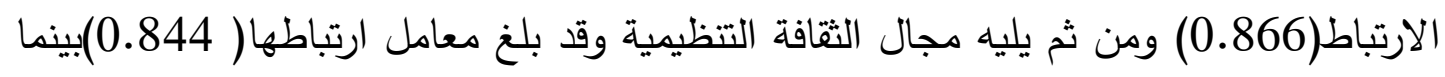

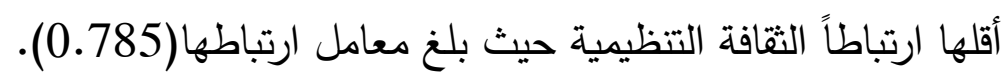

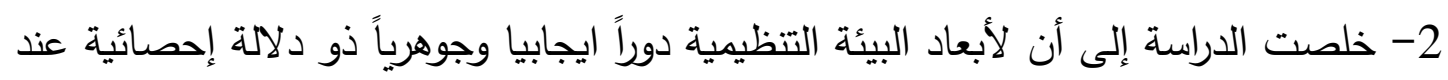

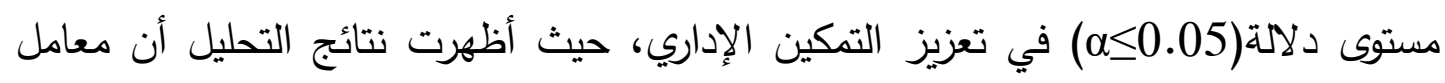

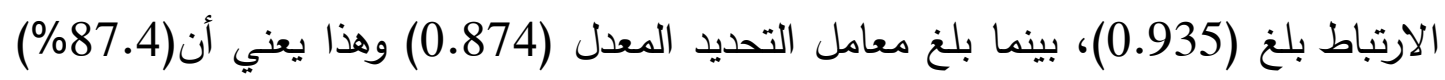
من التغير في تعزيز التمكين الإداري يعود إلى تأثير المتغيرات المستقلة التالية (الهيكل

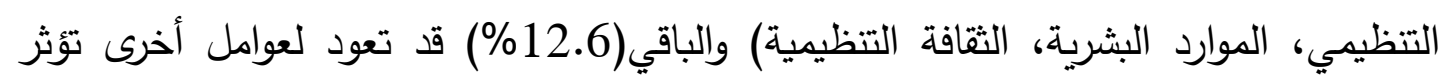
على المتغير التابع في تعزيز التمكين الإداري. 


\section{ب. النتائج الخاصة بالفروق الإحصائية:}

3- لا توجد فروق ذات دلالة إحصائية عند مستوى دلالة(0.059) بين متوسطات آراء

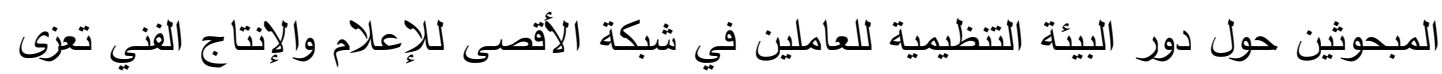

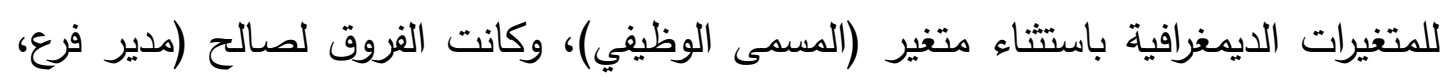

4- لا توجد فروق ذات دلالة إحصائية عند مستوى دلالة (0.05) بين متوسطات آراء

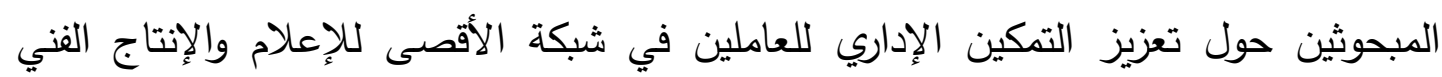

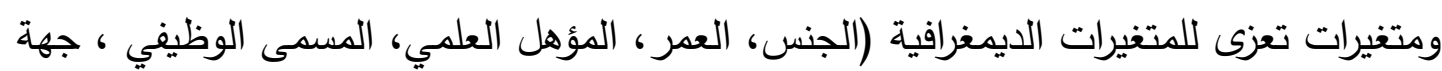

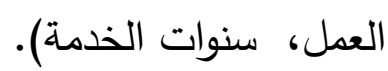
توصيات الدراسة

1- إجراء تعديلات على الهيكل التنظيمي من شأنها إدخال تطويرات تسهم في تحسين البيئة التظظيمية و تفعيل مبدأ تقويض الصلاحيات.

2- بناء سياسات جديدة للاختيار وتعيين الأفراد بحيث تراعي النزاهة والثشفافية وفق مقاييس محددة تكفلها

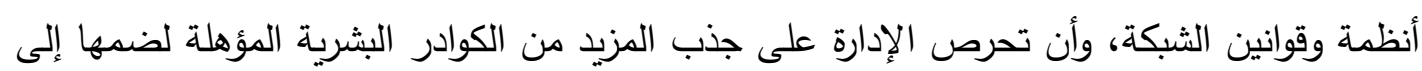

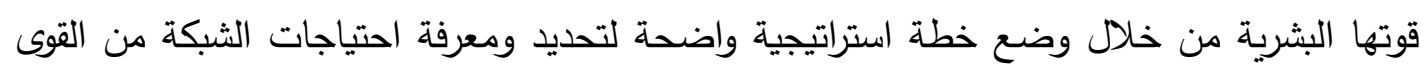

$$
\text { البشرية. }
$$

3- بناء سياسات جديدة تؤكد على رعاية الأفراد وتدفع إلى تحديث الإجراءات المتعلقة بتحديد الاحتياجات التدريبية. 4- بناء سياسات جديدة تؤكد على تقييم الأداء على أسس علمية ومن خلال اجراءات سليمة. 5- تحديد المسار الوظيفي من خلال تطوير السياسات الإدارية المتعلقة بالترقيات.

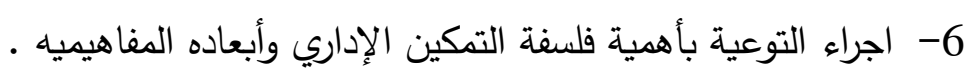

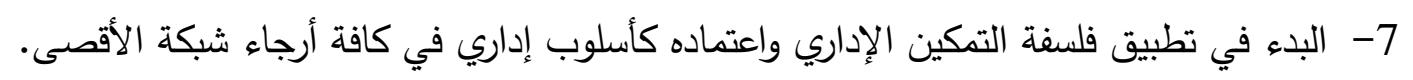

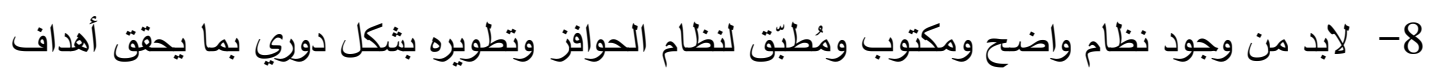

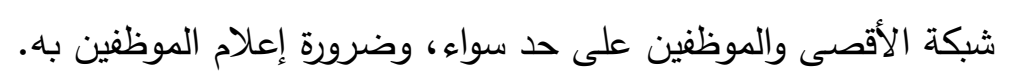

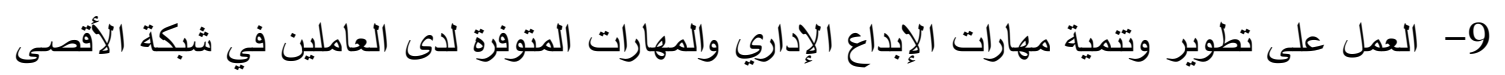

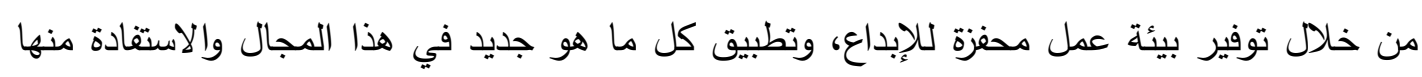
في عقد لقاء ات وندوات للعاملين في الثبكة. 10-أن تقوم إدارة الثبكة بالعمل على تثجيع المبادرات الإبداعية في المشكلات من خلال البحث عن البكاء الأفكار الجديدة والإبداعية.

11-تبني أسلوب و فلسفة العمل الجماعي وتثجع عليه وتقلل من العمل الفردي، وذلك بدعم وتأييد فرق

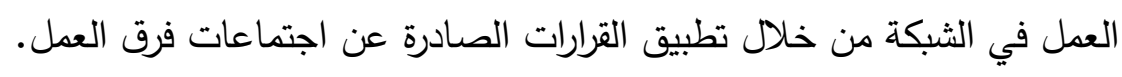


12-تبني برامج التدريب الإداري، والتأهيل المهني للعاملين، وعقد الدورات التدربية، وتوفر مجالات التدريب المستمر خلال فترة العمل.

المراجع

ابن زرعة، نورة (2016):"عناصر الإبداع الإداري لاى قيادات الكليات في جامعة الأميرة نورة بنت عبدالرحمن"،

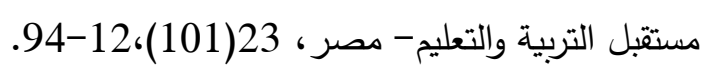

أبو معيلق، أماني(2012):"علاقة الثقافة التظيمية بالالتزام الوظيفي لاى معلمي المدارس الأساسية الحكومية بمحافظة غزة وسبل تطويرها"، فلسطين ، رسالة ماجستير غير منشورة، الجامعة الإسلامية.

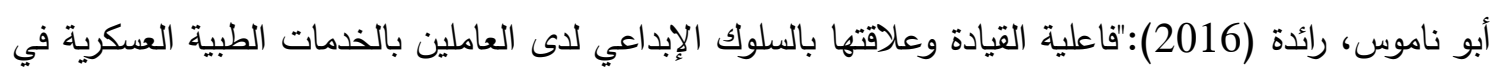
محافظات غزة"، فلسطين، دراسة غير منشورة، أكاديمية الإدارة والسياسة للدراسات العليا.

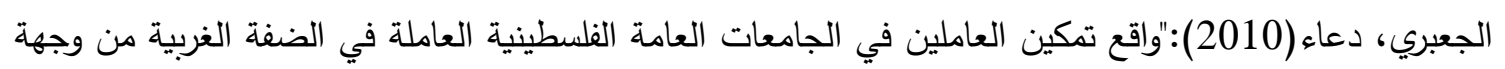
نظر الإداريين"، فلسطين، رسالة ماجستير غير منشورة جامعة الخليل.

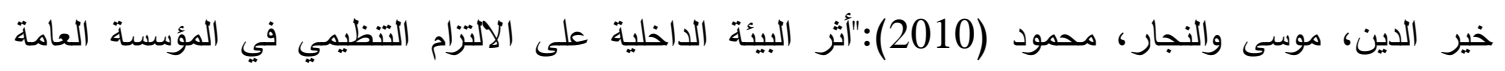
للضمان الاجتماعي في المملكة الأردنية الهاشمية، الأردن.

الزاملي، يوسف (2013):"التمكين وعلاقته بالإبداع لاى مديري مدارس وكالة الغوث الدولية في محافظات غزة"، فلسطين، رسالة ماجستير غير منشورة، الجامعة الإسلامية.

سمارة، نسرين(2017):"واقع إدارة التتوع وأثرها على الثقافة التنظيمية بالجامعات الفلسطينية، فلسطين، محافظات غزة، رسالة ماجستير ، الجامعة الإسلامية.

شقورة، محمد(2015):"متطلبات التمكين الإداري لاى مديري المدارس الثانوية بمحافظات غزة وعلاقتها بثقافة

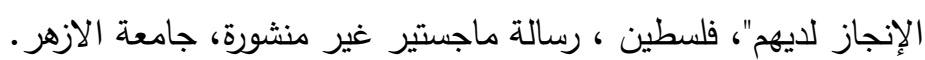

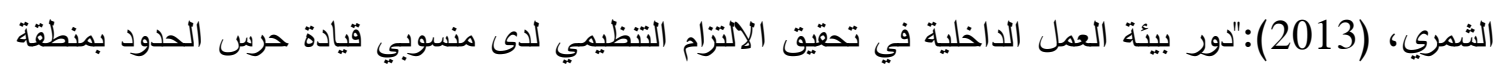
الحدود الثمالية"، السعودية، دراسة غير منشورة، جامعة نايف العربية للعبلة العلوم الأمنية.

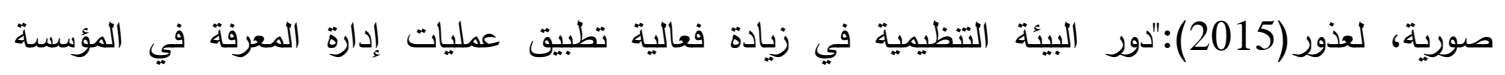
الاقتصادية"، الجزائر ، دراسة حالة مؤسسة كوندور للإلكترونيات بولاية برج بوعريريج، جامعة بسكرة. عبيدة، سامي (2016):"العلاقة بين المناخ التظيمي والسلوك الإبداعي"، فلسطين ، دراسة تطبيقية على الهيئات التدريسية في كليات المجتمع المتوسطة في قطاع غزة" دراسة غير منشورة، الجامعة الإسلامية.

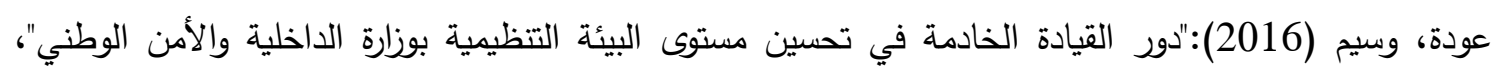
فلسطين ، رسالة ماجستير غير منشورة، أكاديمية الإدارة والسياسة للدراسات العليا. فرحات، صبحي (2017):"المناخ التظيمي وعلاقته بالاتزان الانفعالي لدى العاملين في الإدارة العامة للصحة النفسية"، فلسطين، دراسة غير منشورة، أكاديمية الإدارة والسياسة. المشوط، محمد(2011):"أثر بيئة العمل على الإبداع الإداري"، الكويت ، دراسة تطبيقية على أكاديمية سعد العبدالله للعلوم الأمنية في دولة الكويت، دراسة غير منشورة، جامعة الشرق الاوسط. 


$$
\begin{aligned}
& \text { نصار ، أمجد (2016):"دور بيئة العمل في الالتزام التظيمي من وجهة نظر العاملين في الجامعات الفلسطينية"، } \\
& \text { فلسطين، رسالة ماجستير غير منشورة، أكاديمية الإدارة والسياسة للدراسات العليا. } \\
& \text { الوادي، محمد حسين (2012):"التمكين الإداري في العصر الحديث"، دار الحامد للنشر والتوزيع، ط1، عمان، } \\
& \text { الأردن. } \\
& \text { اليازجي، ابراهيم (2015):"التمكين الإداري وعلاقته بالدافعية للإنجاز لدى رؤساء الأقسام ومدراء الدوائر التابعة }
\end{aligned}
$$

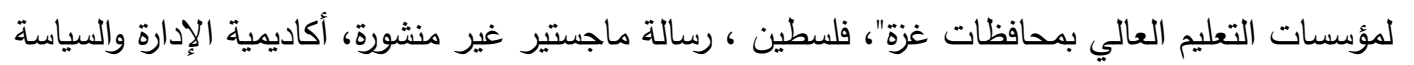

$$
\begin{aligned}
& \text { للدراسات العليا. }
\end{aligned}
$$

\section{References}

Abu Muaylaq, Amani. (2012). The relationship of organizational culture with the career commitment of government basic school teachers in Gaza Governorate and ways to develop it. [Unpublished master's thesis], Faculty of Commerce, Islamic University, Gaza, Palestine. (in Arabic)

Abu Namous, Raeda (2016). Leadership effectiveness and its relation to creative behavior among military medical services personnel in Gaza Governorates, Unpublished master's thesis, Academy of Management and Politics for Postgraduate Studies. (in Arabic)

Akhavan, P., Zahedi, M. R., Dastyari, A., \& Abasaltian, A. (2014). The effect of organizational culture and leadership style on knowledge management in selected research organizations. Citation: Akhavan, Peyman, Zahedi, MR, Dastyari, Akram, and ali Abasaltian, 432-440.

Aktaş, E., Çiçek, I., \& Kıyak, M. (2011). The effect of organizational culture on organizational efficiency: The moderating role of organizational environment and CEO values. Procedia-Social and Behavioral Sciences, 24, 1560-1573.

Alareeni, B. (2018). The impact of firm-specific characteristics on earnings management: evidence from GCC countries. International Journal of Managerial and Financial Accounting, 10(2), 85-104.

Alareeni, B. (2018). Does corporate governance influence earnings management in listed companies in Bahrain Bourse?. Journal of Asia Business Studies, 12(4), 551-570.

Alareeni, B., \& Aljuaidi, O. (2014). The modified Jones and Yoon models in detecting earnings management in Palestine Exchange (PEX). International Journal of Innovation and Applied Studies, 9(4), 1472.

Alareeni, B., \& Branson, J. (2013). Predicting Listed Companies' Failure in Jordan Using Altman Models: A Case Study. International Journal of Business and Management, 8(1), 113-126.

Alareeni, B., \& Deghish, H. (2016). Applicability of the balanced scorecard to assess performance of Al-Aqsa Media Network Institution in Gaza Strip. IUG Journal of Economics and Business.

Alareeni, B.A. (2019). The associations between audit firm attributes and audit qualityspecific indicators: A meta-analysis. Managerial Auditing Journal, 43(1), 6-43.

Al-Jabari, Doaa. (2010). The reality of empowering workers in Palestinian public universities operating in the West Bank from the administrative point of view. [Unpublished master's thesis], Hebron University. (in Arabic) 
Al-Magableh, M., \& Otoum, A. (2014). The administrative empowerment and its relationship with the innovative behavior among the head/coordinators of the academic department at the Faculty of Science and Arts, Sharurah-Najran University. International Research in Education, 2(2), 83-106.

Al-Mashout, Muhammad. (2011). The impact of work environment on administrative creativity, an applied study on Saad Al-Abdullah Academy for Security Sciences in the State of Kuwait. [Unpublished master's thesis], Middle East University. (in Arabic)

Alqallaf, H. and Alareeni, B. (2018). Evolving of Selected Integrated Reporting Capitals among Listed Bahraini Banks. International Journal of Business Ethics and Governance, 1(1), pp. 15-36.

Al-Shammari, (2013). The role of the internal work environment in achieving the organizational commitment of the border guards command in the Northern borders region. [Unpublished master's thesis], Saudi Arabia, Naif Arab University for Security Sciences. (in Arabic)

Al-Wadi, Muhammad Hussein. (2012). Administrative empowerment in the modern era", Al-Hamid House for Publishing and Distribution, 1st Edition, Amman, Jordan. (in Arabic)

Al-Yazji, Ibrahim. (2015). Administrative empowerment and its relation to the motivation for achievement among heads of departments and directors of departments of Higher Education Institutions in Gaza Governorates. [Unpublished master's thesis], Academy of Management and Politics for Postgraduate Studies. (in Arabic)

Al-Zamili, Yousef (2013). Empowerment and its relationship to creativity among UNRWA school principals in Gaza governorates. [Unpublished master's thesis], Islamic University. (in Arabic)

Awadh, M., \& Alareeni, B. (2018). Measuring level of voluntary disclosures of banks listed in Bahrain Bourse. J Account Mark, 7(295), 2.

Farhat, Subhi. (2017). Organizational climate and its relationship to emotional balance among workers in the General Administration of Mental Health. [Unpublished master's thesis], Academy of Management and Policy. (in Arabic)

Ibn Zarah, Noura. (2016). The elements of administrative creativity among college leaders at Princess Noura Bint Abdulrahman University, the Future of Education Egypt, 23 (101), 12-94. (in Arabic)

Jones, Gareth R. (2004): Organizational theory, Design, and change, Fifth Edition, Prentice Hall, New Jersey.

Khair al-Din, Musa and al-Najjar, Mahmoud. (2010). The impact of the internal environment on the organizational commitment of the social security corporation in the Hashemite Kingdom of Jordan, Jordan. (in Arabic)

Nassar, Amjad. (2016). The role of the work environment in organizational commitment from the perspective of employees in Palestinian universities. [Unpublished master's thesis], Academy of Management and Policy for Postgraduate Studies. (in Arabic)

Obaidah, Sami. (2016). The relationship between organizational climate and creative behavior-an applied study on teaching bodies in community colleges in the gaza strip. [Unpublished master's thesis], Islamic University. (in Arabic)

Odeh, Wasim (2016). The role of servant leadership in improving the level of the organizational environment at the Ministry of Interior and National Security. [Unpublished master's thesis], Academy of Management and Policy for Postgraduate Studies. (in Arabic) 
Pozveh, A. Z., \& Karimi, F. (2016). The Relationship between Organizational Climate and the Organizational Silence of Administrative Staff in Education Department. International Education Studies, 9(6), 120-129.

Rankouh, A. \& Poor, P. (2013). Examine the Relationship between Organizational Culture and Creativity of Lecturers. Universal Journal of Management and Social Sciences, 3, (8), 24-31.

Samara, Nisreen. (2017). The reality of diversity management and its impact on the organizational culture in Palestinian universities, [Unpublished master's thesis], Palestine, Islamic University. (in Arabic)

Shaqoura, Muhammad. (2015). Administrative empowerment requirements for secondary school in Gaza Governorates and their relation to their culture of achievement, [Unpublished master's thesis], Palestine, Al-Azhar University. (in Arabic)

Soria, Lazur (2015), The role of the organizational environment in increasing the effectiveness of the application of knowledge management processes in the economic enterprise, Algeria, a case study of the Condor Electronics Corporation in the wilaya of Bordj Bou Arreridj, University of Biskra. (in Arabic)

Touama, H (2015). The Impact of Application of the Organizational Empowerment Strategy in Enhancing the Organizational Creativity in Jordanian Universities A Case Study of Zarqa University in Jordan, International Journal of Managerial Studies and Research (IJMSR), 3(4), 2349-0330.

Weshah, H. A. (2012). The perception of empowerment and delegation of authority by teachers in Australian and Jordanian schools: A comparative study. European Journal of Social Sciences, 31(3), 359-375. 